Review

\title{
Emerging Advances of Detection Strategies for Tumor-Derived Exosomes
}

\author{
Huijuan Cheng $1,2,3,4$, Qian Yang ${ }^{1,2,3,4}$, Rongrong Wang 1,2,3,4 $\mathbb{D}$, Ruhua Luo 1,2,3,4 $\mathbb{D}^{\text {, Shanshan Zhu }}{ }^{5}$, \\ Minhui Li 1,2,3,4, Wenqi Li 1,2,3,4 Cheng Chen 1,2,3,4, Yuqing Zou 1,2,3,4, Zhihua Huang 1,2,3,4, Tian Xie 1,2,3,4 \\ Shuling Wang ${ }^{1,2,3,4, *}$, Honghua Zhang ${ }^{1,2,3,4, *}$ and Qingchang Tian 1,2,3,4,*(D)
}

check for updates

Citation: Cheng, H.; Yang, Q.; Wang, R.; Luo, R.; Zhu, S.; Li, M.; Li, W.; Chen, C.; Zou, Y.; Huang, Z.; et al Emerging Advances of Detection Strategies for Tumor-Derived Exosomes. Int. J. Mol. Sci. 2022, 23, 868. https://doi.org/10.3390/ ijms23020868

Academic Editor: Arnaud Bianchi

Received: 18 December 2021

Accepted: 11 January 2022

Published: 14 January 2022

Publisher's Note: MDPI stays neutral with regard to jurisdictional claims in published maps and institutional affiliations.

Copyright: (C) 2022 by the authors. Licensee MDPI, Basel, Switzerland. This article is an open access article distributed under the terms and conditions of the Creative Commons Attribution (CC BY) license (https:// creativecommons.org/licenses/by/ $4.0 /)$.
1 College of Pharmacy, Hangzhou Normal University, Hangzhou 311121, China huijuancheng1994@163.com (H.C.); qiandecade@163.com (Q.Y.); rong123450609@163.com (R.W.); 18327602598@163.com (R.L.); lmh5546@163.com (M.L.); 117816111674@163.com (W.L.); jinshaner1@dingtalk.com (C.C.); 2021112012252@stu.hznu.edu.cn (Y.Z.); hzh9799@gmail.com (Z.H.); xbs@hznu.edu.cn (T.X.)

2 Key Laboratory of Elemene Class Anti-Cancer Chinese Medicines, Hangzhou Normal University, Hangzhou 311121, China

3 Engineering Laboratory of Development and Application of Traditional Chinese Medicines, Hangzhou Normal University, Hangzhou 311121, China

4 Collaborative Innovation Center of Traditional Chinese Medicines of Zhejiang Province, Hangzhou Normal University, Hangzhou 311121, China

5 Public Health Institutes, Hangzhou Normal University, Hangzhou 311121, China; 2019213001043@stu.hznu.edu.cn

* Correspondence: wsling222@163.com (S.W.); erin6@163.com (H.Z.); tianqc@hznu.edu.cn (Q.T.)

\begin{abstract}
Exosomes derived from tumor cells contain various molecular components, such as proteins, RNA, DNA, lipids, and carbohydrates. These components play a crucial role in all stages of tumorigenesis and development. Moreover, they reflect the physiological and pathological status of parental tumor cells. Recently, tumor-derived exosomes have become popular biomarkers for non-invasive liquid biopsy and the diagnosis of numerous cancers. The interdisciplinary significance of exosomes research has also attracted growing enthusiasm. However, the intrinsic nature of tumorderived exosomes requires advanced methods to detect and evaluate the complex biofluid. This review analyzes the relationship between exosomes and tumors. It also summarizes the exosomal biological origin, composition, and application of molecular markers in clinical cancer diagnosis. Remarkably, this paper constitutes a comprehensive summary of the innovative research on numerous detection strategies for tumor-derived exosomes with the intent of providing a theoretical basis and reference for early diagnosis and clinical treatment of cancer.
\end{abstract}

Keywords: exosomes; tumor-derived exosomes; molecular biomarkers; detection methods

\section{Introduction}

The currently defined exosome (40-150 nm) was discovered in sheep reticulocytes in 1983 [1,2]. Johnstone et al. [3] tracked transferrin receptors in the process of reticulocytes' maturation and suggested that the generation of exosomes is the mechanism for the loss of transferrin receptors in mature erythrocytes. More and more studies have shown that exosomes exist in bodily fluids and participate in intercellular communication. Furthermore, they appear as specific early warnings for cancer such as breast cancer [4] and pancreatic cancer [5], tumors such as melanoma [6], and mental illness such as Alzheimer's [7] and Parkinson's disease [8,9].

Tumors possess complex tissues composed of matrix components (such as fibroblasts, mesenchymal cells, smooth muscle cells, pericytes, etc.), immune cells, platelets, and endothelial cells related to heterogeneous subcells. Through the secretion of soluble factors, cytokines, and exosomes, cancer cells continuously reshape their environment by recruiting 
and activating surrounding cells [10]. Exosomes are secreted from cancer cells, and the specific antigens on their surface can reflect the nature of donor cells [11]. A multifold of the current reviews in exosomes focused on exosomal physical characterization, separation, and labeling for semiquantitative analyses [12-16]. However, introducing novel detection and clinical diagnostic methods of tumor-derived exosomes is not comprehensive enough. This paper summarizes the biological origin, composition, molecular markers, and clinical diagnosis of exosomes, analyzes the relationship between exosomes and tumors, and summarizes the precise and quantitative detection methods of tumor-derived exosomes and their clinical potential.

\section{Exosomes}

\subsection{Synthesis and Release of Exosomes}

Cells release various types of vesicles to transmit information between cells. These vesicles are divided into apoptotic bodies (>1000 nm), microvesicles (200 1000 nm), and exosomes $(40 \sim 150 \mathrm{~nm})[16,17]$. The latter are membranous vesicles formed by living cells through the process of "endocytosis-fusion-efflux", divided into the following four stages: initiation, endocytosis, multivesicular bodies (MVB) formation, and exosomal secretion [18]. Nano-scale exosomes penetrate cell membranes and infiltrate many biological fluids such as blood, urine, saliva, synovial fluid, breast milk, etc. The schematic diagram of the synthesis and release of exosomes is displayed in Figure 1. The early stage of exosomal formation consists of intraluminal vesicles produced by cells through endocytosis. With the entry of heat shock proteins, microRNAs (miRNAs), enzymes, and other loading molecules in the cytoplasm, more and more intramural vesicles are formed. Finally, MVBs are formed, which subsequently fuse with the cell membrane to secrete exosomes outside the cell [18]. The modulation of MVB, exosomal synthesis and release is through the endosomal sorting complexes required for the transport (ESCRT) pathway or an ESCRTindependent mechanism during the process [19-21]. MVBs are eventually either delivered to the lysosome to be degraded along with its components or fused with the cell's plasma membrane to release its content, including exosomes, into the extracellular space [22-25]. Although the effect of ESCRT in MVB synthesis has been extensively studied, whether MVB produced by the ESCRT-dependent pathway is degraded by lysosomes or fused with the cytoplasm to release exosomes, as well as its regulatory mechanism, remains elusive [26-28].

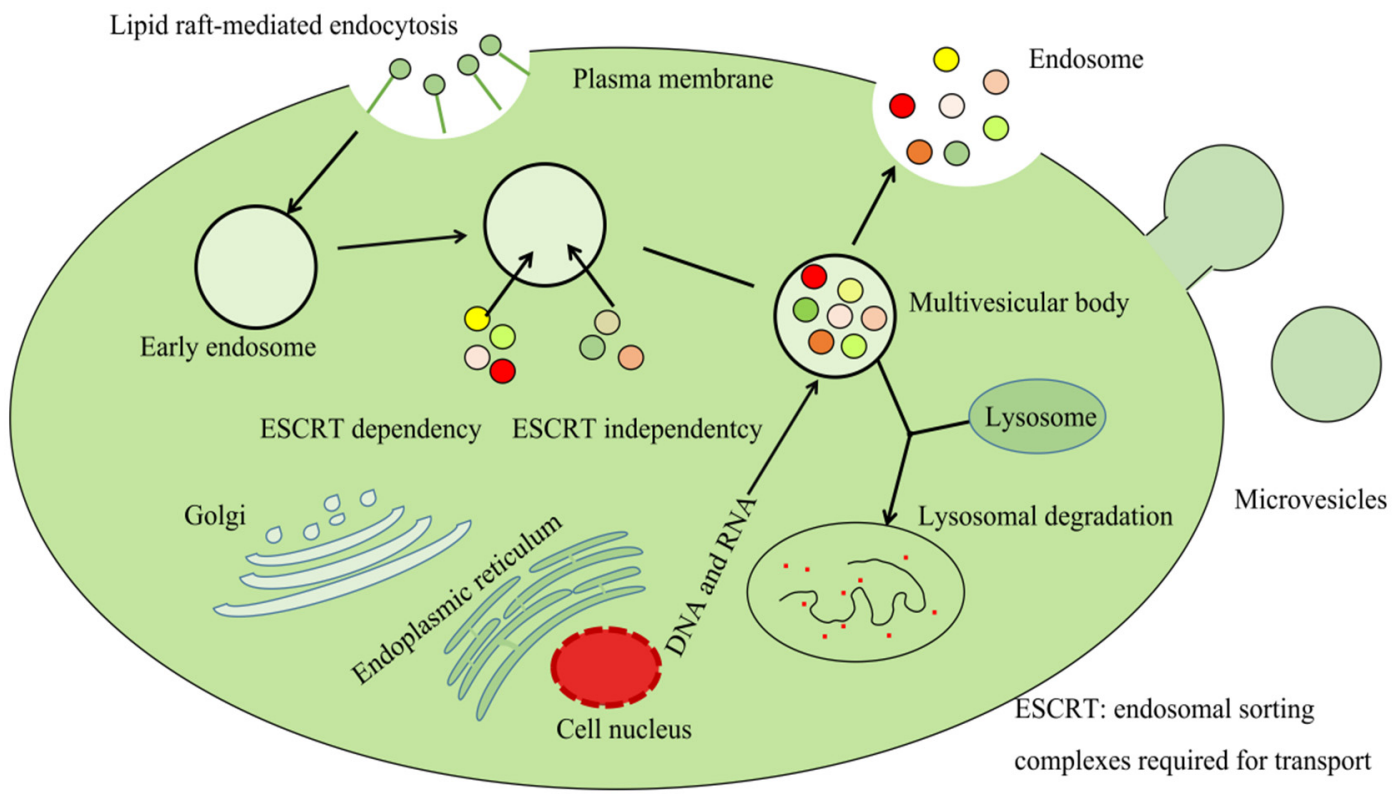

Figure 1. The schematic diagram of the synthesis and release of exosomes. 


\subsection{Components in Exosomes}

\subsubsection{Exosomal Nucleic Acid}

Specific nucleic acids that mutant mRNA such as the heterogeneous nuclear ribonucleoproteins (hnRNPH1) in serum contained in exosomes may possibly serve as reliable biomarkers for liver cancer [29]. Unique miRNAs in exosomes could also message diagnosis and observe the evolution of cancer. For example, exosomal miR-165-3p is increased in the urine of patients with bladder cancer and relates to advanced disease stage [30]. In another instance, exosomal miR-423-5p level in the serum of patients with gastric carcinoma enhance gastric cancer cell proliferation and migration by targeting the tumor suppressor of fused protein (SUFU) [31]. Analyses of exosomes derived from plasma revealed a miRNA profile that may enable the detection of breast tumors [32].

DNA in exosomes may provide information about cancer-specific mutations [33,34]. Indeed, genomic sequencing revealed that exosomes in the serum of glioma cancer patients carry human-specific DNA sequences relevant for glioblastoma multiforme (GBM) biology [35]. Additionally, driver mutations associated with pancreatic ductal adenocarcinoma (PDAC) were identified in this exosomal DNA [33]. The chances of whole genomic sequencing of serous exosomes in cancer patients may provide information for diagnosing and predicting treatment outcomes.

\subsubsection{Exosomal Proteins}

The proteins in exosomes are composed of the transmembrane family and endosomal proteins. On the one hand, the transmembrane family includes membrane transport protein (Annexins and Rabs), regular immune molecules such as major histocompatibility complexes (MHC), class I, and MHC class II molecules; acceptors, integrins, transmembrane proteins (CD81, CD82, CD9, and CD63), etc. On the other hand, endosomal proteins include chaperone proteins (Hsp60, Hsp70, Hsc70, and Hsp90), skeleton proteins (Profilin, Tubulin, Cofilin, etc.), synthetic proteins (Clatherin, Ubiqulin, Alix and TSG-101), signal proteins such as ADP-ribosylation factors 1 (ARF1), phosphatidylinositol 3-kinase (PI3K), and cell division cycle 42 (CDC42), enzymes such as pyruvate kinase (PK), protein kinase G (PKG), ATPases, etc., and cancer-associated specific markers such as glypican-1 (GPC-1), epithelial cell adhesion molecule (EpCAM), programmed death ligand 1 (PD-L1), and epidermal growth factor receptor (EGFR). Exosomal proteins likely mirror their cellular origin and may also facilitate the detection of cancer. As a matter of fact, GPC-1 was detected in the serum of pancreatic carcinoma, which discriminated patients with pancreatic ductal adenocarcinoma from those with benign pancreas diseases, such as chronic pancreatitis [36]. Moreover, exosomes containing CD63 significantly increase in melanoma patients and can be served as markers for tumor detection [37,38].

Exosomes not only play a vital role in regulating conventional physiological processes, such as stem cell maintenance [39], tissue repair [40], and immune regulation [41], but also play crucial roles in tumor treatment [42]. The schematic diagram of exosomal components is illustrated in Figure 2.

Exosomal molecular markers have brought innovative ideas to the diagnosis and treatment of tumors, indicating satisfactory clinical significance. The exosome is a tremendous hub in physiological or pathological processes; therefore, the development of non-invasive diagnostic methods with higher sensitivity and specificity based on exosomes has enormous potential for the early diagnosis, treatment evaluation, and prognostic analysis of diseases. Now, the relationship between tumor and exosomal molecular markers is summarized below (Table 1). 


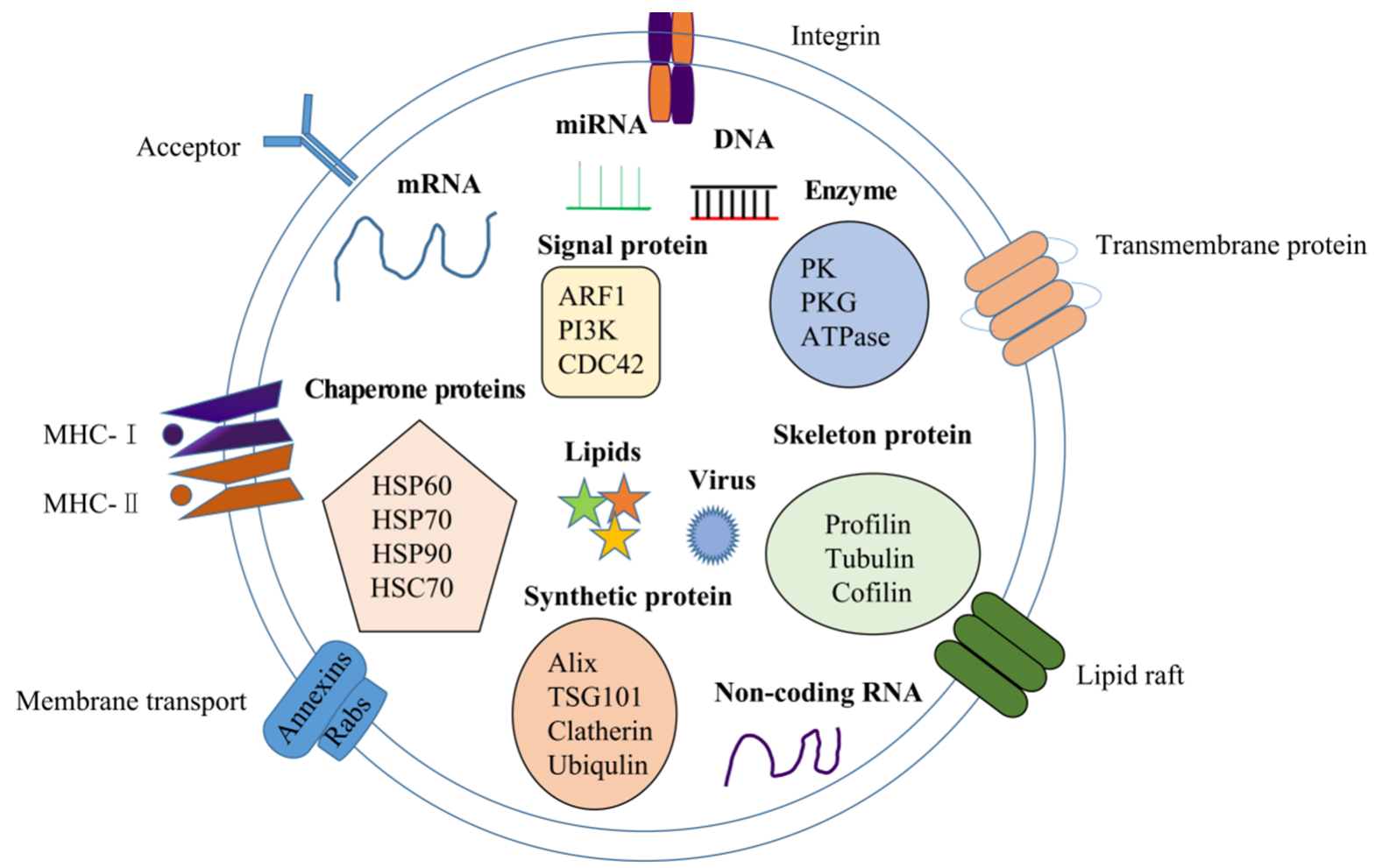

Figure 2. The schematic diagram of exosomal components.

Table 1. Clinical significance of molecular markers of tumor-derived exosomes.

\begin{tabular}{|c|c|c|c|c|c|c|c|}
\hline Scheme & $\begin{array}{c}\text { Cancer } \\
\text { Type }\end{array}$ & $\begin{array}{c}\text { Marker } \\
\text { Type }\end{array}$ & Name & Expression & Source & Clinical Value & Ref. \\
\hline \multirow{4}{*}{$\begin{array}{l}\text { Central } \\
\text { nervous }\end{array}$} & \multirow{4}{*}{ Glioma } & DNA & IDH1 mutation & \multirow{4}{*}{$\uparrow$} & Serum & Diagnosis, Prognosis & [35] \\
\hline & & mRNA & EGFRvIII & & $\begin{array}{l}\text { cerebrospinal } \\
\text { fluid }\end{array}$ & Diagnosis & {$[43,44]$} \\
\hline & & miRNA & $\begin{array}{l}\mathrm{miR}-454-3 \mathrm{P} / \mathrm{miR}- \\
\text { 320/miR-574-3P }\end{array}$ & & Serum & $\begin{array}{c}\text { Diagnosis, Prognosis } \\
\text { judgment }\end{array}$ & {$[45,46]$} \\
\hline & & snRNA & RNU6-1 & & Serum & $\begin{array}{c}\text { Diagnosis, Prognosis } \\
\text { judgment }\end{array}$ & [46] \\
\hline \multirow{6}{*}{ Thoracic } & \multirow{3}{*}{$\begin{array}{l}\text { Lung } \\
\text { cancer }\end{array}$} & mRNA & $\begin{array}{c}\text { BRAF/EGFR/FRS2/ } \\
\text { GREB1/LZTS1 }\end{array}$ & \multirow{6}{*}{$\uparrow$} & saliva & Diagnosis & [47] \\
\hline & & miRNA & $\begin{array}{l}\mathrm{miR}-451 \mathrm{a} / \mathrm{miR}- \\
\text { 425-3p/miR-4257 }\end{array}$ & & $\begin{array}{l}\text { Serum } \\
\text { plasma }\end{array}$ & $\begin{array}{l}\text { Recurrence/Resistance/ } \\
\text { Prognosis judgment }\end{array}$ & {$[48-50]$} \\
\hline & & Protein & Tim-3/LBP/LRG1 & & $\begin{array}{c}\text { Serum/ } \\
\text { plasma/Urine }\end{array}$ & $\begin{array}{c}\text { Transferrer/Staging/ } \\
\text { Diagnosis }\end{array}$ & {$[51-53]$} \\
\hline & \multirow{3}{*}{$\begin{array}{l}\text { Breast } \\
\text { tumors }\end{array}$} & mRNA & hTERT & & Serum & \multirow{3}{*}{$\begin{array}{l}\text { Early diagnosis/ } \\
\text { Recurrence }\end{array}$} & [54] \\
\hline & & miRNA & miR-223-3P & & Plasma & & [32] \\
\hline & & Protein & $\mathrm{FN}$ & & Plasma & & [55] \\
\hline
\end{tabular}


Table 1. Cont.

\begin{tabular}{|c|c|c|c|c|c|c|c|}
\hline Scheme & $\begin{array}{l}\text { Cancer } \\
\text { Type }\end{array}$ & $\begin{array}{l}\text { Marker } \\
\text { Type }\end{array}$ & Name & Expression & Source & Clinical Value & Ref. \\
\hline \multirow{18}{*}{ Digestive } & $\begin{array}{l}\text { Esophageal } \\
\text { cancer }\end{array}$ & miRNA & $\begin{array}{l}\text { miR-21/RUN6- } \\
\text { 1/miR-16-5p }\end{array}$ & $\uparrow$ & Serum & Diagnosis & {$[56,57]$} \\
\hline & \multirow{3}{*}{$\begin{array}{c}\text { Gastric } \\
\text { carcinoma }\end{array}$} & miRNA & $\begin{array}{l}\text { miR-423-5p/ } \\
\text { miR-21,miR-1225- } \\
\text { 5p/miR-23b }\end{array}$ & $\uparrow /-/ \downarrow$ & $\begin{array}{c}\text { Serum/ } \\
\text { Peritoneal } \\
\text { lavage } \\
\text { fluid/Plasma }\end{array}$ & $\begin{array}{l}\text { Diagnosis, Prognosis } \\
\text { judgment/ } \\
\text { Recurrence/Recurrence, } \\
\text { Prognosis judgment }\end{array}$ & {$[31,58,59]$} \\
\hline & & LncRNA & UFC1 & $\uparrow$ & Serum & $\begin{array}{c}\text { Diagnosis, Prognosis } \\
\text { judgment }\end{array}$ & [60] \\
\hline & & Protein & TRIM3 & $\downarrow$ & Serum & Diagnosis & [61] \\
\hline & \multirow{6}{*}{$\begin{array}{l}\text { Colorectal } \\
\text { cancer }\end{array}$} & mRNA & KRTAP5/MAGEA3 & \multirow{6}{*}{$\uparrow$} & Serum & - & \multirow{2}{*}{ [62] } \\
\hline & & LncRNA & BCAR4 & & Serum & - & \\
\hline & & \multirow[t]{2}{*}{ miRNA } & \multirow{2}{*}{$\begin{array}{c}\operatorname{miR}-6803-5 P \\
\operatorname{miR}-548 c-5 p \\
\operatorname{miR}-92 a-3 p\end{array}$} & & Serum & $\begin{array}{c}\text { Transferrer/Staging/ } \\
\text { Diagnosis }\end{array}$ & \multirow[t]{2}{*}[63,64]{} \\
\hline & & & & & & Diagnosis/Transferrer & \\
\hline & & circRNA & Circ-KLDHC10 & & Serum & - & [65] \\
\hline & & Protein & $\begin{array}{c}\text { TAG72/CA125/ } \\
\text { CPNE3 }\end{array}$ & & Plasma & $\begin{array}{c}\text { Resistance/Transferrer/ } \\
\text { Diagnosis, Prognosis } \\
\text { judgment }\end{array}$ & [66-68] \\
\hline & \multirow{6}{*}{$\begin{array}{l}\text { Liver } \\
\text { cancer }\end{array}$} & mRNA & hnRNPH1 & $\uparrow$ & Serum & Diagnosis & [29] \\
\hline & & & $\operatorname{miR}-638$ & $\downarrow$ & \multirow{3}{*}{ Serum } & \multirow{3}{*}{ Diagnosis } & {$[69]$} \\
\hline & & miRNA & miR-122 & $\uparrow$ & & & \multirow{2}{*}{ [70] } \\
\hline & & & miR-148a & $\uparrow$ & & & \\
\hline & & LncRNA & LINC00635 & $\uparrow$ & Serum & $\begin{array}{c}\text { Diagnosis, Prognosis } \\
\text { judgment }\end{array}$ & [71] \\
\hline & & Protein & LG3BP/PIGR & $\uparrow$ & Serum & Diagnosis & {$[72]$} \\
\hline & \multirow{2}{*}{$\begin{array}{l}\text { Pancreatic } \\
\text { carcinoma }\end{array}$} & miRNA & $\begin{array}{l}\mathrm{miR}-191 / \mathrm{miR}- \\
\text { 21/miR-451a }\end{array}$ & \multirow[t]{2}{*}{$\uparrow$} & \multirow[t]{2}{*}{ Serum } & \multirow[t]{2}{*}{ Diagnosis } & [73] \\
\hline & & Protein & $\mathrm{GPC}^{+}$ & & & & [36] \\
\hline \multirow{5}{*}{ Urinary } & \multirow{3}{*}{$\begin{array}{l}\text { Bladder } \\
\text { cancer }\end{array}$} & miRNA & miR-615-3p & \multirow{5}{*}{$\uparrow$} & Urine & \multirow{5}{*}{$\begin{array}{c}\text { Diagnosis, Prognosis } \\
\text { judgment }\end{array}$} & {$[30]$} \\
\hline & & LncRNA & MALAT1/PCAT-1 & & Urine & & [74] \\
\hline & & Protein & TACSTD2/EDIL-3 & & Urine & & {$[75,76]$} \\
\hline & \multirow{2}{*}{$\begin{array}{l}\text { Kidney } \\
\text { cancer }\end{array}$} & miRNA & $\begin{array}{l}\operatorname{miR}-210 / \\
\operatorname{miR}-1233\end{array}$ & & Serum & & [77] \\
\hline & & Protein & $\begin{array}{l}\text { MMP9/PODXL/ } \\
\text { DKK4 }\end{array}$ & & Urine & & [78] \\
\hline
\end{tabular}

\section{Exosomes and Tumor Development}

The cargo of extracellular vesicles reflecting the cell of origin has opened a new frontier for non-invasive biomarker discovery in oncology [79]. Specific tumor-derived extracellular vesicles are released into the extracellular space and can be found in the plasma, serum, and urine of patients presenting with tumors [80]. The main functions of exosomes in intercellular communication are to promote the growth of primary cancers, stimulate angiogenesis, activate stromal fibroblasts, remodel cancer extracellular matrix, and inhibit the host's immune response [10]. In the process of tumor formation, exosomes can use advantages of their structure and composition to modulate immune system function, form a microenvironment that is conducive to tumor formation, and induce malignant tumor 
behavior [81]. Sung et al. [82] suggested that the auto-secretion of exosomes boosted the movement of cancer cells by enhancing the transient polarization and adhesion in other ways. It is reasonable to hypothesize that the biological occurrence of inhibitory exosomes may largely lead to the loss of cancer cell migration, which will provide a feasible strategy for eliminating exosomes secreted in the tumor area and inhibiting the occurrence, development, and metastasis of cancer cells. Lopatina et al. [83] demonstrated how the IL-3R $\alpha$ blockade on tumor-endothelial cells reprograms extracellular vesicles, which then acquire the ability to change the expression of Vimentin, $\beta$-catenin, and TWIST1, and reduce angiogenesis and the metastatic spread of primary tumors. By comparing the miRNA map of ovarian cancer with the tumor-derived exosomal map separated from the oophoroma patient, Taylor et al. [84] demonstrated the association between miRNA and circulating tumor-derived exosomes, and the results implied that miRNA analysis of circulating tumor exosomes could be used as an alternative diagnostic biomarker for biopsy analysis, extending its usefulness to screening asymptomatic populations.

The relationship between exosomes and tumor development is summarized below: tumor-derived exosomes transfer carcinogens such as oncoproteins, mRNA, etc., from aggressive tumor cells to resting or normal cells, accelerating the malignant transformation of these cells, thereby bolstering the occurrence of tumors. These exosomes can regulate the occurrence of tumors by modulating the immune system, reshaping the tumor microenvironment, and promoting angiogenesis. The schematic diagram of the relationship between tumor-derived exosomes and tumors is presented in Figure 3.

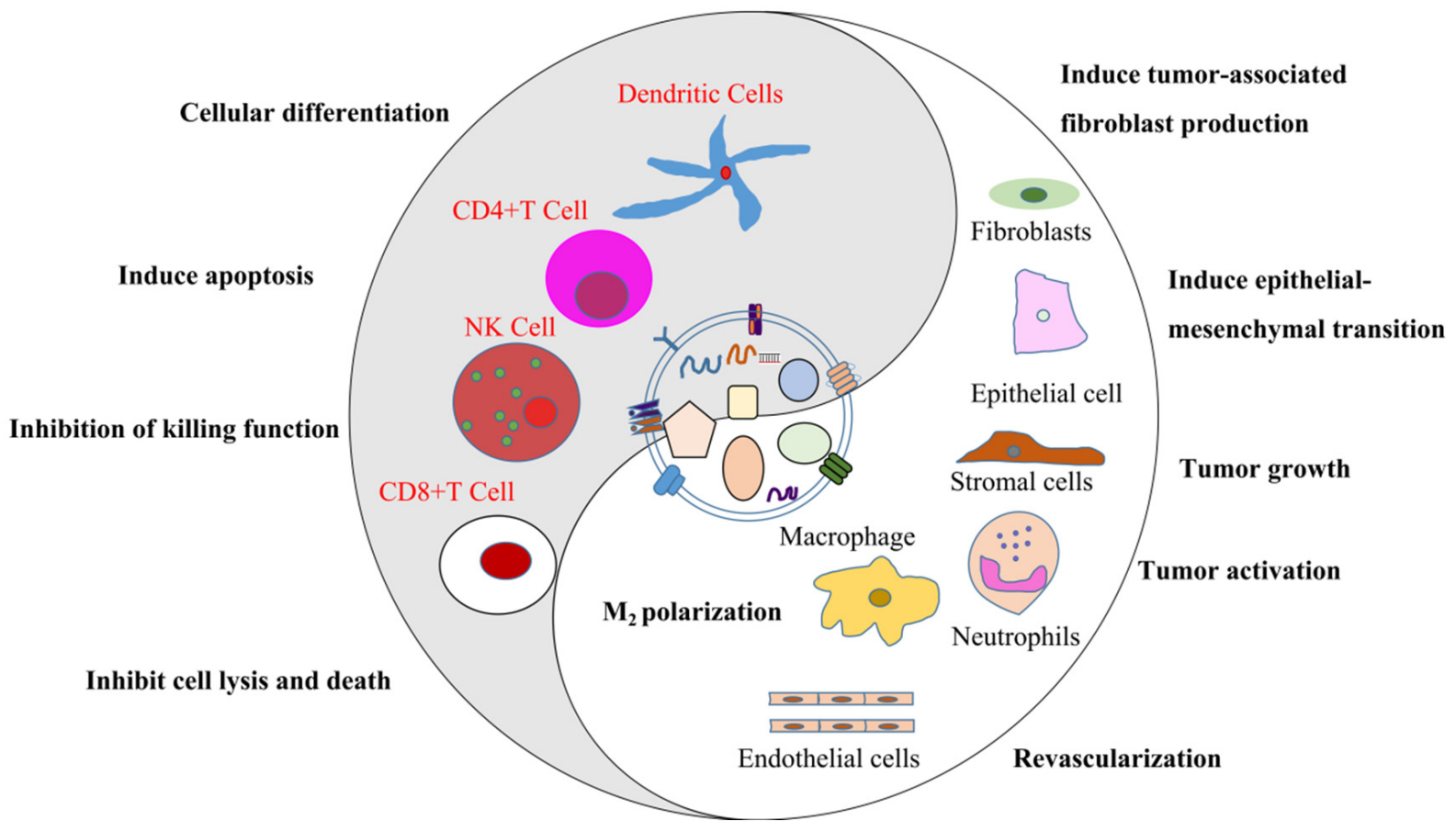

Figure 3. The schematic diagram of the relationship between tumor-related exosomes and tumors. Tumor-derived exosomes directly induce immune tolerance by transmitting inhibited or apoptotic signals to immune cells, indirectly affecting immune cells' development, maturation, and anti-tumor activity. These exosomes alter the function of the responding cells by passing miRNA/mRNA/DNA to immune cells, polarizing macrophages into M2 type that accelerates tumor progression, converting normal fibroblasts into tumor-associated ones, promoting angiogenesis of endothelial cells, inhibiting the killing function of natural killer (NK) cells, and by triggering the differentiation of dendritic cells to promote the occurrence and development of tumors. 


\section{Novel Detection Methods of Tumor-Derived Exosomes}

The size and density of exosomes are relatively close to lipoproteins and protein complexes, and diverse separation and purification methods will affect their purity and quality. At present, a variety of separation and purification schemes have been established based on exosomes' physical and chemical properties, such as ultracentrifugation, immunomagnetic beads, commercial kits, etc. $[85,86]$. In contrast, exosomes with protein or nucleic acid biomarkers are detected by enzyme-linked immunosorbent assay (ELISA), polymerase chain reaction (PCR), DNA sequencing, or microarray analysis [87]. In order to further strengthen the feasibility of the application of exosomal molecular biomarkers, researchers have been struggling to optimize the procedures for exosomal separation. Due to the benefits of speed, integration, and small sample size, microfluidic strategies have attracted more and more attention $[88,89]$. At the same time, there are also emerging interdisciplinary technologies based on fluid mechanics and other different engineering fields (such as materials, microelectronics, biomedical engineering, etc.) for the identification of exosomes [90]. Therefore, this article reviews the novel detection methods of tumor-derived exosomes in combination with exosomal molecular biomarkers and tumor diagnosis, which provides a theoretical basis and reference for early cancer diagnosis and clinical treatment.

Because a single method fitting a variety of sample sources is not feasible, efforts have been made to exploit different physicochemical and biochemical properties of exosomes. To date, seven classes of exosome detection strategies have been reported, including sizeexclusion chromatography, droplet digital ELISA (ddELISA), digital droplet PCR (ddPCR), microfluidic techniques, surface-enhanced Raman scattering (SERS) technology, aptamerbased separation method, quantum dot-based exosome quantification, with a unique sets of pros and cons for each technique (Table 2).

\subsection{Separation and Purification}

Separation and purification are the first steps for detection. Size exclusion chromatography is a chromatographic method that separates molecules in a solution according to their size or molecular weight $[108,109]$. The difference between the pore diameter of the gel and the molecular size of the sample is used for separation. The research separated the test substance to an agarose gel chromatography column, further separated the mixed components of the test substance according to the difference in molecular size, and successfully split extracellular vesicles from high-density lipoprotein (HDL) and protein step by step [110]. This provides a groundbreaking idea for the separation of nanoscale extracellular vesicles in a large mass. Zhang et al. [111] developed a method to efficiently separate extracellular vesicles from HDL, low-density lipoprotein (LDL), and very-lowdensity lipoprotein (VLDL) based on differences in surface charge and molecular size by agarose gel electrophoresis. This method is of immense value for separating high-purity extracellular vesicles from plasma and other lipoprotein-contaminated samples. 
Table 2. Comparison of seven types of detection strategies for exosomes and tumors.

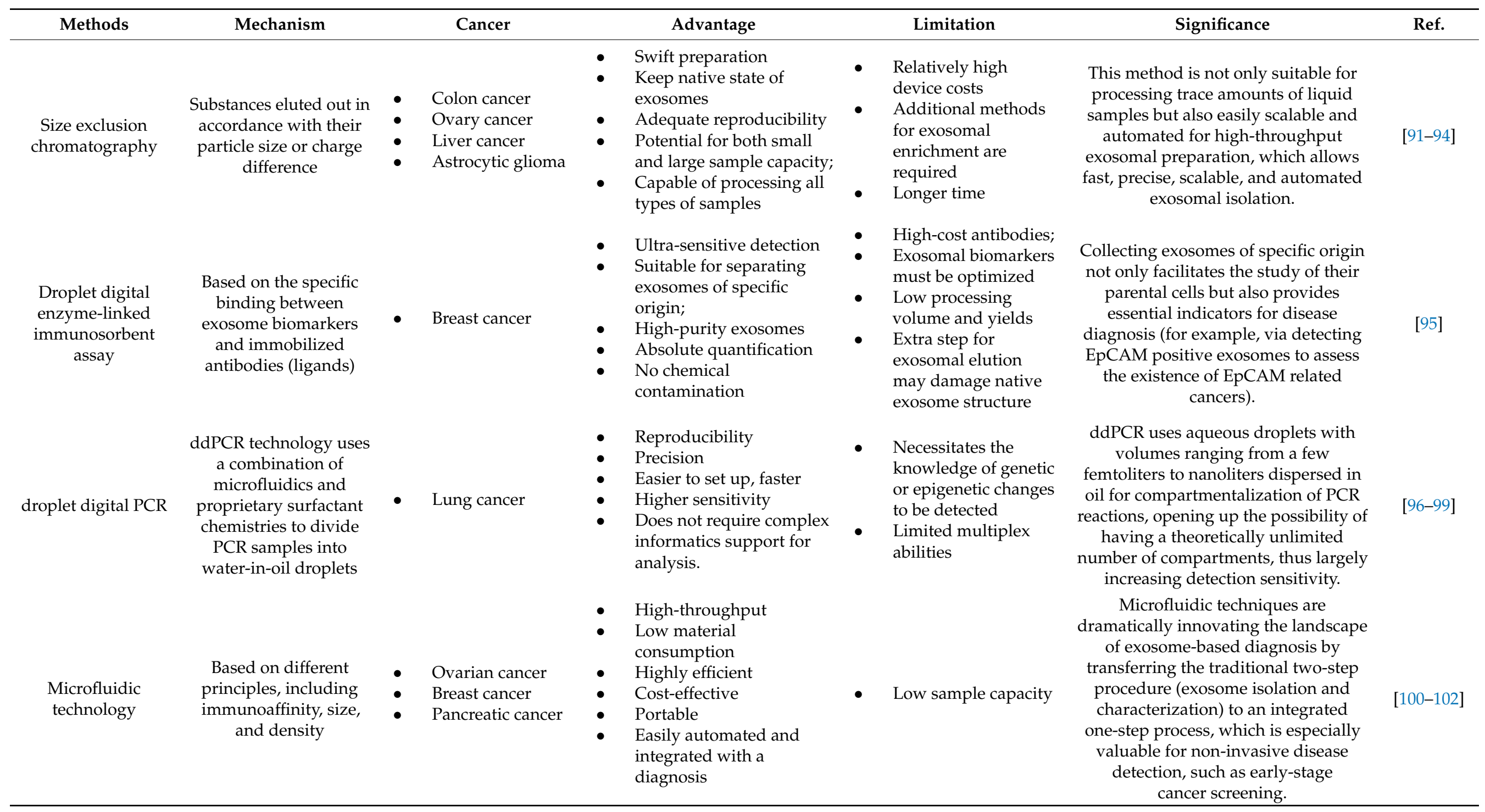


Table 2. Cont.

\begin{tabular}{|c|c|c|c|c|c|c|}
\hline Methods & Mechanism & Cancer & Advantage & Limitation & Significance & Ref. \\
\hline $\begin{array}{c}\text { Surface-enhanced } \\
\text { Raman scattering } \\
\text { technology }\end{array}$ & $\begin{array}{l}\text { SERS is a spectroscopic } \\
\text { phenomenon that } \\
\text { enhances the Raman } \\
\text { signal by absorbing the } \\
\text { molecule on the rough } \\
\text { surface or nanometal } \\
\text { materials. }\end{array}$ & $\begin{array}{l}\text { - } \\
\text { cansmall cell lung } \\
\text { - } \quad \text { Pancreatic cancer }\end{array}$ & $\begin{array}{ll}\text { - } & \text { High enhancement factor } \\
\text { - } & \text { Stable } \\
\text { - } & \text { No quenching and } \\
\text { - } & \text { photobleaching } \\
\text { Fingerprint characteristics } \\
\text { and narrow Raman bands }\end{array}$ & $\begin{array}{l}\text { Raman spectra of } \\
\text { exosomes are } \\
\text { complex and } \\
\text { nonconforming. }\end{array}$ & $\begin{array}{l}\text { Multiple analytes (or biomarkers) in } \\
\text { one sample could be detected in a } \\
\text { single cycle/run when using more } \\
\text { than one SERS tag, which results in an } \\
\text { accurate, efficient, and simplified } \\
\text { diagnosis of diseases. }\end{array}$ & [103-105] \\
\hline $\begin{array}{c}\text { Aptamer-based } \\
\text { separation method }\end{array}$ & $\begin{array}{l}\text { The aptamer is } \\
\text { combined with } \\
\text { oligonucleotides or } \\
\text { peptides as a detection } \\
\text { probe, linked to a } \\
\text { biological vector or } \\
\text { emerging nanomaterials } \\
\text { to achieve target } \\
\text { monitoring }\end{array}$ & $\begin{array}{ll}\text { - } & \text { Prostate cancer } \\
\text { - } & \text { Lung cancer } \\
\text { - } & \text { Breast cancer }\end{array}$ & $\begin{array}{l}\text { - Aptamers are selected for } \\
\text { cell surface biomarkers in } \\
\text { their native state, and } \\
\text { conformation without } \\
\text { previous knowledge of } \\
\text { their biomarkers } \\
\text { High specificity and } \\
\text { affinity } \\
\text { Aptamer-cell affinity } \\
\text { interaction }\end{array}$ & $\begin{array}{l}\text { Bind and release cells } \\
\text { on-demand }\end{array}$ & $\begin{array}{l}\text { The biomarkers and corresponding } \\
\text { aptamers can be exploited to improve } \\
\text { cancer diagnostics and therapies. }\end{array}$ & [106] \\
\hline $\begin{array}{l}\text { Quantum } \\
\text { dot-based exosome } \\
\text { quantification }\end{array}$ & $\begin{array}{l}\text { Using quantum dots as } \\
\text { signal amplifiers }\end{array}$ & $\begin{array}{l}\text { - } \quad \text { Breast cancer } \\
\text { - } \quad \text { Colon cancer }\end{array}$ & $\begin{array}{l}\text { - High specificity and } \\
\text { sensitivity } \\
\text { - Using QDs for the signal } \\
\text { enhancement } \\
\text { - Considerable reduction in } \\
\text { biofouling issues }\end{array}$ & $\begin{array}{ll}- & \text { Magnetic wash } \\
- & \text { Purification steps }\end{array}$ & $\begin{array}{l}\text { The approach could potentially } \\
\text { represent an effective bioassay for the } \\
\text { quantification of disease-specific } \\
\text { exosomes in clinical samples. }\end{array}$ & [107] \\
\hline
\end{tabular}




\subsection{Digital Detection of Proteins and Nucleic Acids}

The measurements of multiple biomolecules in the same biological sample are vital for diagnosing or classifying clinical diseases. However, the content of these disease-related biomarkers in biological fluids is usually very low, so ultra-sensitive measurement methods are required [112]. In recent years, digital ELISA and digital PCR platforms have revolutionized detection technologies for the absolute quantification of nucleic acids and proteins with microfluidics [113-115]. Cohen et al. [116] developed a ddELISA for ultrasensitive detection of single protein molecules. This is a quantitative method to distinguish lowlevel proteins and exosomes with digital ELISA and droplet microfluidics. The ddELISA achieves maximum sensitivity by improving sampling efficiency and counting more target molecules. This will facilitate the discovery of countless biomarkers that have never been measured before clinical applications. The ddPCR is an emerging technology capable of absolute nucleic acid quantification without using standard curves [117]. This ddPCR technology combines microfluidics and proprietary surfactant chemistries to separate PCR samples into water-in-oil droplets [98]. Meanwhile, Cho et al. [118] reported the identification of Mycobacterium tuberculosis DNA from exosomes isolated from tuberculosis patients and suggested higher sensitivity by using exosomal DNA than using total DNA. Additionally, tumor-derived exosomes can be identified by tumor-specific biomarkers via antibody labeling. Lin et al. [119] developed a dual-target-specific aptamer recognition activated in situ connection system on exosome membrane combined with ddPCR for the quantitation of tumor-derived exosomal PD-L1 (Exo-PD-L1). The working principle of the highly sensitive quantification of tumor-derived Exo-PD-L1 using aptamer-based proximity ligation assay is as follows: Two types of designed aptamer probes against EpCAM and PD-L1 were utilized to simultaneously label both types of protein biomarkers on the exosome. The extended parts of two aptamers are in close proximity because of the fluidity of the exosomal membrane. After ligation, ddPCR is performed to quantify the ligation products. Similarly, Wang et al. [113] developed a ddPCR system based on an oil saturated polydimethylsiloxane (PDMS) microfluidic chip platform for the quantification of lung cancer related miRNAs. This droplet PCR system provides new possibilities for highly sensitive and efficient detection of cancer-related genes.

\subsection{Microfluidic Technology}

Recently, microfluidic platforms have revolutionized detection technologies with highthroughput and rapid detection of exosomes, which have been employed in subpopulation typing $[100,101,120,121]$. Microfluidic technology has the upper edge in terms of low material consumption, low pollution, and a small sample required for analysis, and hence is considered a promising technology [122].

\subsubsection{Acoustics-Based Microfluidics}

The acoustics-based microfluidic device is a robust particle manipulation strategy to exert radiation forces on particles. Under acoustic pressure, particles endure differential forces according to their mechanical properties (size, density, compressibility) [123,124]. Lee et al. [125] designed a microfluidic chip based on acoustic fluid technology to separate microvesicles and exosomes from the culture supernatant of ovarian cancer cells. Interactive digital converting electrodes were installed in the middle of the device to control the radiating force of the acoustic wave and adjust the sample flow rate. Large particles moved more rapidly along both sides of the flow, whereas smaller particles flowed along the middle. At the end of the device, the large and small particles were collected by different channels. This system could further extend the usefulness of acoustofluidics for microvesicle analysis. Indeed, $\mathrm{Wu}$ et al. [122] reported that the purification efficiency of exosomes and other extracellular vesicles from whole blood reached $98.4 \%$ by integrating acoustic and microfluidic technologies. This integrated chip technology can directly isolate exosomes and other types of extracellular vesicles from undiluted whole blood samples in an automated manner. 


\subsubsection{Immunoaffinity-Based Microfluidics}

The capturing methods combined with immune-affinity and microfluidic technology are highly efficient, specific, and rapid, and are currently mainly applied for tumor-derived exosomal separation. To realize the digital qualification of target exosomes, a droplet digital microfluidic chip was fabricated for single exosome counting to identify the heterogeneity of exosomes. Liu et al. [126] described a new digital detection method based on droplet microfluidics technology to count single exosomes for breast cancer diagnosis. First, the immuno-magnetic beads are used to capture the exosomes in the sample, based on the Poisson distribution principle. Then, an ExoELISA reaction is carried out to connect the captured exosomes with a fluorescent reaction enzyme. Next, the magnetic bead complex is formed on the microdroplet chip, together with the fluorescent reaction substrate, to form microdroplets such that each droplet contains at most one magnetic bead. In this case, each droplet contains at most one exosome. Only exosomes expressing distinct diagnostic biomarkers (GPC-1) are connected with a fluorescent reaction enzyme, which catalyzes the fluorescence of the substrate in the droplet. Finally, the digital detection of exosomes is realized by counting the fluorescent droplets. Zhao et al. [127] designed an ExoSearch exosome separation chip device to separate plasma exosomes from patients with ovarian cancer. The collected exosomes were stained with a fluorescent dye such as Cy-5, Rhodamine, and fluorescein isothiocyanate (FITC) labeling antibodies (anti-CA125, anti-EpCAM, and anti-CD24) for multicolor fluorescence imaging at a low limit of detection of $7.5 \times 10^{5}$ particles $\mathrm{mL}^{-1}$. The ExoSearch chip possesses two fluid injection ports on the chip: one end is used to inject the plasma sample to be tested, and the other end is used to inject the immunomagnetic bead solution containing specific antibodies. Through the serpentine channel, the Dean vortex and the inertial lift are generated to promote the complete mixing of the two streams and then captured by the magnetic field. Kanwar et al. [128] outlined an ExoChip chip with a layer of biotinylated CD63 antibody on the surface of the microfluidic device channel to capture exosomes containing CD63 antigens from the cell culture supernatant and serum of pancreatic cancer patients. The captured exosomes were quantified with a lipophilic membrane fluorescent carbocyanine dye (Dio).

\subsection{Surface-Enhanced Raman Scattering Technology}

Raman spectroscopy is a method to analyze the vibration mode of a sample by measuring the inelastic scattering effect caused by the radiation laser [129]. The combination of Raman spectra and microfluidic technology creates new opportunities for system miniaturization and integration [130]. Furthermore, SERS is a spectroscopic phenomenon that enhances the Raman signal by absorbing the molecule on the rough surface or nanometal materials [103]. In recent times, SERS has been employed to detect and differentiate exosomes derived from different cells [131-133]. The cancer-specific molecular composition differentiates the cancer exosomes from other exosomes [134]. Wang et al. [135] developed a microfluidic Raman biochip to isolate and analyze exosomes in situ. The exosomes were enriched by anti-CD63 magnetic nanoparticles through the mixing channel of the staggered triangular column array. The enriched exosomes were then magnetically fixed on the Raman spectra detection area, and antibody EpCAM functionalized Raman beads with high-density nitrile and used them as probes. By simply monitoring the intensity of the $2230 \mathrm{~cm}^{-1}$ SERS peak of prostate cancer and normal prostate cells, exosomes can be quantitatively detected. This novel device may have the potential as a clinical exosomal analysis tool for prostate cancer. Park et al. [133] further demonstrated the Raman spectra of lung cancer and normal cell-derived exosomes by combining SERS and statistical pattern analysis. In short, SERS spectra of exosomes were analyzed by principal component analysis. By employing this pattern analysis, lung-cancer-cell-derived exosomes were clearly distinguished from normal ones with a sensitivity of $95.3 \%$ and a specificity of $97.3 \%$. Shin et al. [136] demonstrated an accurate diagnosis of early-stage lung cancer using exosomal deep learning-based SERS. The deep learning model predicted that plasma 
exosomes of $90.7 \%$ of patients $(n=43)$ had higher similarity to lung cancer cell exosomes than the average of the healthy controls and lung cancer with an area under the curve (AUC) of 0.912 for the whole cohort, and stage I patients with an AUC of 0.910. These results exposed the tremendous potential of the combination of exosomal analysis and deep learning as a method for early-stage liquid biopsy of lung cancer.

\subsection{Aptamer-Based Separation Method}

An aptamer with high specificity and affinity discerns and connects to their targets, such as antibodies, and has been used to establish affinity-based isolation of exosomes [137]. For instance, a coating agent composed of EpCAM-affinity peptide aptamer (Ep114) and zwitterionic poly-2-methacryloyloxyethyl phosphorylcholine (MPC) polymer has been used for exosome isolation [138]. Kaushik et al. [139] took advantage of MB@SiO2@Au nanoparticles modified with a CD63 nucleic acid aptamer to capture exosomes from cancer patients' plasma. In order to achieve high efficiency, sensitive and specific detection, Darmanis et al. [140] developed a sensitive plasma protein analysis by microparticle-based proximity ligation assays, which relies on the simultaneous recognition of the target protein by three antibody molecules to enhance specificity. This method can perform stable and highly sensitive protein detection in complex biological materials based on paramagnetic particles. Wan et al. [141] construed a method to modify DNA nanocomponents depending on molecular recognition on the surface of nano-scale exosomes. This in situ assembly method is based on molecular recognition between DNA aptamers and their exosomal surface biomarkers, and DNA hybridization chain reactions induced by aptamer-chimeric triggers. It is worth noting that functional DNA nanostructures are assembled on nanosized exosomes. This strategy has laid a scientific foundation for further exploration of biomedical applications related to exosomes.

Compared with antibody-based capture methods, aptamer-based capture methods may have a higher potential in exosomal separation because of their high binding affinity toward the protein biomarker on the surface of tumor-derived exosomes [142].

\subsection{Quantum Dot-Based Exosome Quantification}

In many electrochemical sensors, a signal amplification step based on nanomaterials is usually used to detect immune response events $[143,144]$. In particular, incorporating inorganic-colloid tracers such as quantum dots (QDs) as a signal transduction label, combined with an anodic stripping voltammetric readout, was widely reported to significantly enhance the sensitivity of immunoassays [145,146].

To date, several other electrochemical methods based on aptamer and horseradish peroxidase (HRP) mediated amplifications have also been developed and executed to quantify exosomes [147,148]. For example, Wu et al. [149] developed sensors based on magnetic and fluorescent biological probes (MFBPs) for one-step quantification of exosomes in oral cancer. Within the MFBPs, self-assembled DNA concatamers loaded with numerous QDs were ingeniously tethered to aptamers and anchored on the surface of magnetic microspheres. The aptamer's efficient recognition and capture of an exosome would simultaneously provoke the release of a DNA concatamer as the detection signal carrier, thereby generating a "one exosome-numerous QDs" amplification effect. This research provides a new, universal strategy for sensitive and quantitative analysis of exosomes from body fluids, thereby promoting the development of exosome-based liquid biopsy techniques. Moreover, Boriachek et al. [107] combined exosomes on magnetic beads with exosomal-specific antibodies, then used CdSeQD-functionalized specific antibodies to isolate tumor-derived specific exosomes. Here, QDs are used as signal amplifiers to determine tumor-derived specific exosomes by combining voltammetry and immunological technologies. This method is predominantly applied to tumor-derived specific exosomal protein antibodies such as FAM134B for colon and human epidermal growth factor receptor2 (HER2) for breast cancer, which represents a promising bioassay technology. 


\subsection{Emerging Nanomaterial Detection Technology}

The covalent organic framework (COF) has received more and more attention due to its diverse structure and distinct functions. Wang et al. [150] researched, designed, and manufactured a new type of COF-based nanoprobe, in which spherical COFs are functionalized with gold nanoparticles (AuNPs) modified with para-sulfocalix[4]arene hydrate (pSC4) and HRP, called HRP-pSC(4)-AuNPs@COFs. It was subsequently used for the electrochemical detection of colorectal cancer-derived exosomes. In this design, pSC(4), as a friendly linker, can recognize and bind various amino acid residues on the surface of exosomes, whereas AuNPs, with excellent conductivity, can accelerate the migration of charge carriers and improve the response of the biosensor. It is worth noting that the high porosity of $\mathrm{COF}$ allows them to load a large amount of HRP, giving colorectal cancer a high catalytic activity. This method has also been used to analyze clinical serum samples and can successfully distinguish colorectal cancer patients from healthy ones, indicating considerable potential in clinical diagnosis. Moreover, Wang et al. [151] designed a microfluidic device with a multi-dimensional layered structure of silicon cilia micropillars, which is primarily based on the size of the particles to achieve exosomal separation and capture exosomes with a diameter of 30 200 nm. The device electrolessly etches silicon nanowires on the sidewalls of micropillars with the aid of electrodeposited silver nanoparticle catalysts. A porous microstructure is then formed to capture particles, and finally, the porous silicon nanowires are dissolved in phosphate buffer (PBS) to acquire exosomes. The nanowire has a long and thin morphology and a large surface area, which facilitates modification of the surface and assists in the capture of the target particles. Lim et al. [152] designed a magnetic nanowire device to capture exosomes. The surface of the nanowire is covered with three kinds of antibodies: CD9, CD63, and CD81, which can capture exosomes expressing these three membrane proteins in the sample. Iron oxide nanoparticles can be captured by a magnetic field, and finally, dithiothreitol is processed to obtain exosomes.

\section{Single Exosome Phenotyping Technique}

The phenotypic analysis of a single exosome is a new technology that perfectly combines immunology and optics [153]. With the help of single exosome phenotyping technology, oncologists can analyze tumor-related exosomes in more depth so as to better conduct tumor pathophysiological research, early screening, diagnosis, and clinical management. Hoshino et al. [154] determined the specific protein biomarkers derived from cancer cells by detecting the exosomal proteome of tumors, tumors' surrounding tissues, and serum. After further analysis of the exosomal proteome in cancer patients, healthy tissues, and serum, the specificity and accuracy of the test results attained more than $90 \%$. Clearly, by detecting the contents of serum exosomes, the type of tumor can be determined. The researchers used a single exosome phenotyping technique to analyze exosomes derived from human plasma and successfully detected exosomes carrying moesin and $\beta_{2}$-microglobulin proteins, and quantitative analysis was performed on them. Crescitelli et al. [155] developed a method for isolating exosomes in order to distinguish the subtypes of exosomes derived from metabolic melanoma and analyzed the isolated exosomal subtypes. Next, the researchers divided the exosomes derived from melanoma tissues at different centrifugal speeds into two types: large and small. For the two exosomes, the single exosome phenotyping technique and ELISA method identified three protein biomarkers: CD9, CD63, and CD81. The single exosomes phenotyping technique also detected CD41a, a biomarker derived from platelets, which inferred that the sample was contaminated with trace amounts of exosomes derived from blood. Quaglia et al. [156] established that small exosomes of castration-resistant prostate cancer cells overexpress $\alpha \mathrm{V} \beta 3$ and can promote tumor growth and neuroendocrine differentiation. In contrast, small exosomes of cells that do not express $\alpha \mathrm{V} \beta 3$ do not have such an effect. Afterward, the researchers used a single exosome phenotyping technique to detect whether the isolated small exosomes contained $\alpha \mathrm{V} \beta 3$. The results projected that exosomes captured by the corresponding antibodies for protein biomarkers capable of forming ligands with $\alpha \mathrm{V} \beta 3$ (except CD41) contained $\alpha \mathrm{V} \beta 3$. However, for CD41, which 
does not form a ligand with $\alpha \mathrm{V} \beta 3, \alpha \mathrm{V} \beta 3$-containing exosomes were not detected. Härkönen et al. [157] used gastric cancer cells MKN74 to study the impact of CD44 expression on exosomal secretion, hyaluronic acid synthesis, and tumor cell growth. The researchers used a single exosome phenotyping technique to detect the content of CD44 and other biomarkers in the unpurified medium of MKN74 cells and the isolated and purified exosomes. The results exhibited that the MOCK (CD44 knockout) cell group had a significant decrease in the number of secreted exosomes in the unpurified medium and after separation and purification, compared with the control group. The above results signify that the single exosome phenotyping technique can directly detect the culture medium in a complex environment without the separation and purification steps, and the detection results are highly specific.

In the above studies, the single exosome phenotyping technique accurately detected the content of specific exosomes in body fluids and culture media with extremely high sensitivity and specificity. As an early diagnostic tool for cancer, exosomes and the application of exosome-loaded treatment methods will have a clear direction for cancer diagnosis and treatment research in the future. The single exosome phenotyping technology will provide accurate experimental results in future research to help humans overcome cancer.

\section{Conclusions}

Herein, various detection techniques of tumor-derived exosomes were systematically reviewed, and the clinical diagnostic conclusions based on exosomal molecular biomarkers and common cancers have been illustrated. Several portable, fully integrated exosomal biosensors provide a swift response, low detection limit, and high sensitivity, which can be plausible approaches for point-of-care testing.

As a minimally invasive method, exosomal research can reflect the overall molecular information of tumors and can be repeatedly sampled for large-scale monitoring. It has substantial advantages for tumor diagnosis and treatment. As natural vesicles of lipid bilayers, exosomes are also promising drug carriers and have tremendous potential for development in tumor treatment, providing research strategies for the individualized, targeted therapy of tumors. Due to their unique structure and function, exosomes have prospective applications under both pathological and physiological conditions. However, there are still certain limitations in the practical application of exosomes. Because many normal cells continuously release exosomes, it is incredibly challenging to isolate and analyze tumor-derived exosomes in a large population. As the original intent of liquid biopsy, qualitative detection of total exosomes may never achieve the goal of dynamically monitoring tumor progression. In order to apply exosomal technologies to clinical diagnosis as soon as possible, it is imperative to eliminate the interference of normal exosomes as far as possible, focus on the detection of tumor-derived exosomes subgroups, and discover more specific biomarkers for tumor exosomes so that single exosome detection is always the direction of future development. After all, most studies on protein biomarkers are limited to membrane proteins, whereas protein biomarkers in exosomes have not yet been explored. Therefore, proteomics analysis may promote the discovery of protein biomarkers inside exosomes.

Author Contributions: S.W., T.X., Q.T. drafted the work organized co-author to write this review, and give final approval of the version to be published. H.C., Q.Y., R.W., R.L., M.L., W.L., C.C., S.Z., H.Z. accomplished the main text of manuscript. Additionally, H.C., Q.Y., R.L., Y.Z., Z.H. accomplished the tables and abbreviations in the manuscript. H.C., Q.T. accomplished the figure in the manuscript. All authors have read and agreed to the published version of the manuscript.

Funding: This research received no external funding. 
Acknowledgments: This work was supported by Zhejiang Provincial Natural Science Foundation of China (LY20H160008), the Joint Funds of the Zhejiang Provincial Natural Science Foundation of China under Grant No. LHDMZ22H300001, The National Natural Science Foundation of China (82074052), Key Research Project of Zhejiang Provincial Traditional Chinese Medicine Science and Technology Program (2022ZZ024), Key projects of National Natural Science Foundation of China (81730108).

Conflicts of Interest: The authors declare no conflict of interest.

\begin{tabular}{|c|c|}
\hline MVB & multivesicular bodies \\
\hline microRNAs & miRNAs \\
\hline ESCRT & $\begin{array}{l}\text { endosomal sorting complexes required for the } \\
\text { transport }\end{array}$ \\
\hline hnRNPH1 & heterogeneous nuclear ribonucleoproteins \\
\hline SUFU & suppressor of fused protein \\
\hline GBM & glioblastoma multiforme \\
\hline PDAC & pancreatic ductal adenocarcinoma \\
\hline MHC & major histocompatibility complexes \\
\hline ARF1 & ADP-ribosylation factors 1 \\
\hline PI3K & phosphatidylinositol 3-kinase \\
\hline CDC42 & cell division cycle 42 \\
\hline PK & pyruvate kinase \\
\hline PKG & protein kinase $\mathrm{G}$ \\
\hline GPC-1 & glypican-1 \\
\hline EpCAM & epithelial cell adhesion molecule \\
\hline PD-L1 & programmed death ligand 1 \\
\hline EGFR & epidermal growth factor receptor \\
\hline NK & natural killer \\
\hline ELISA & enzyme-linked immunosorbent assay \\
\hline PCR & polymerase chain reaction \\
\hline ddELISA & digital droplet ELISA \\
\hline ddPCR & droplet digital PCR \\
\hline SERS & surface-enhanced Raman scattering \\
\hline HDL & high-density lipoprotein \\
\hline LDL & low-density lipoprotein \\
\hline VLDL & very-low-density lipoprotein \\
\hline Exo-PD-L1 & exosomal PD-L1 \\
\hline PDMS & polydimethylsiloxane \\
\hline FITC & fluorescein isothiocyanate \\
\hline AUC & area under the curve \\
\hline MPC & methacryloyloxyethyl phosphorylcholine \\
\hline QDs & quantum dots \\
\hline HRP & horseradish peroxidase \\
\hline MFBPs & magnetic and fluorescent biological probes \\
\hline HER2 & human epidermalgrowth factor receptor- 2 \\
\hline $\mathrm{COF}$ & covalent organic framework \\
\hline AuNPs & gold nanoparticles \\
\hline pSC4 & para-sulfocalix[4]arene hydrate \\
\hline PBS & phosphate buffer \\
\hline
\end{tabular}

\section{References}

1. Harding, C.; Heuser, J.; Stahl, P. Receptor-mediated endocytosis of transferrin and recycling of the transferrin receptor in rat reticulocytes. J. Cell Biol. 1983, 97, 329-339. [CrossRef]

2. Pan, B.T.; Johnstone, R.M. Fate of the transferrin receptor during maturation of sheep reticulocytes in vitro: Selective externalization of the receptor. Cell 1983, 33, 967-978. [CrossRef]

3. Johnstone, R.M. Maturation of reticulocytes: Formation of exosomes as a mechanism for shedding membrane proteins. Biochem. Cell Biol. Biochim. Biol. Cell 1992, 70, 179. [CrossRef] [PubMed]

4. Wang, M.; Ji, S.; Shao, G.; Zhang, J.; Zhao, K.; Wang, Z.; Wu, A. Effect of exosome biomarkers for diagnosis and prognosis of breast cancer patients. Clin. Transl. Oncol. 2018, 20, 906-911. [CrossRef] 
5. Nilsson, J.; Skog, J.; Nordstrand, A.; Baranov, V.; Mincheva-Nilsson, L.; Breakefield, X.O.; Widmark, A. Prostate cancer-derived urine exosomes: A novel approach to biomarkers for prostate cancer. Br. J. Cancer 2009, 100, 1603-1607. [CrossRef]

6. Petersen, K.E.; Manangon, E.; Hood, J.L.; Wickline, S.A.; Fernandez, D.P.; Johnson, W.P.; Gale, B.K. A review of exosome separation techniques and characterization of B16-F10 mouse melanoma exosomes with AF4-UV-MALS-DLS-TEM. Anal. Bioanal. Chem. 2014, 406, 7855-7866. [CrossRef] [PubMed]

7. Fiandaca, M.S.; Kapogiannis, D.; Mapstone, M.; Boxer, A.; Eitan, E.; Schwartz, J.B.; Abner, E.L.; Petersen, R.C.; Federoff, H.J.; Miller, B.L.; et al. Identification of preclinical Alzheimer's disease by a profile of pathogenic proteins in neurally derived blood exosomes: A case-control study. Alzheimers Dement. 2015, 11, 600-607.e1. [CrossRef] [PubMed]

8. $\quad$ Fraser, K.B.; Moehle, M.S.; Daher, J.P.L.; Webber, P.J.; Williams, J.Y.; Stewart, C.A.; Yacoubian, T.A.; Cowell, R.M.; Dokland, T.; Ye, T.; et al. LRRK2 secretion in exosomes is regulated by 14-3-3. Hum. Mol. Genet. 2013, 22, 4988-5000. [CrossRef]

9. Fraser, K.B.; Rawlins, A.B.; Clark, R.G.; Alcalay, R.N.; Standaert, D.G.; Liu, N.J.; West, A.B.; Parkinson's Dis Biomarker Program. Ser(P)-1292 LRRK2 in urinary exosomes is elevated in idiopathic Parkinson's disease. Mov. Disord. 2016, 31, 1543-1550. [CrossRef] [PubMed]

10. Tomasetti, M.; Lee, W.; Santarelli, L.; Neuzil, J. Exosome-derived microRNAs in cancer metabolism: Possible implications in cancer diagnostics and therapy. Exp. Mol. Med. 2017, 49, e285. [CrossRef]

11. Zhang, Y.; Bi, J.; Huang, J.; Tang, Y.; Du, S.; Li, P. Exosome: A Review of Its Classification, Isolation Techniques, Storage, Diagnostic and Targeted Therapy Applications. Int. J. Nanomed. 2020, 15, 6917-6934. [CrossRef]

12. Boriachek, K.; Islam, M.N.; Moller, A.; Salomon, C.; Nguyen, N.T.; Hossain, M.S.A.; Yamauchi, Y.; Shiddiky, M.J.A. Biological Functions and Current Advances in Isolation and Detection Strategies for Exosome Nanovesicles. Small 2018, 14, 1702153. [CrossRef] [PubMed]

13. Chiang, C.Y.; Chen, C.C. Toward characterizing extracellular vesicles at a single-particle level. J. Biomed. Sci. 2019, 26, 9. [CrossRef]

14. Jeppesen, D.K.; Fenix, A.M.; Franklin, J.L.; Higginbotham, J.N.; Zhang, Q.; Zimmerman, L.J.; Liebler, D.C.; Ping, J.; Liu, Q.; Evans, R.; et al. Reassessment of Exosome Composition. Cell 2019, 177, 428-445.e18. [CrossRef] [PubMed]

15. Shao, H.; Im, H.; Castro, C.M.; Breakefield, X.; Weissleder, R.; Lee, H. New Technologies for Analysis of Extracellular Vesicles. Chem. Rev. 2018, 118, 1917-1950. [CrossRef] [PubMed]

16. Thery, C.; Witwer, K.W.; Aikawa, E.; Alcaraz, M.J.; Anderson, J.D.; Andriantsitohaina, R.; Antoniou, A.; Arab, T.; Archer, F.; Atkin-Smith, G.K.; et al. Minimal information for studies of extracellular vesicles 2018 (MISEV2018): A position statement of the International Society for Extracellular Vesicles and update of the MISEV2014 guidelines. J. Extracell. Vesicles 2018, 7, 1535750. [CrossRef]

17. Gurunathan, S.; Kang, M.H.; Jeyaraj, M.; Qasim, M.; Kim, J.H. Review of the Isolation, Characterization, Biological Function, and Multifarious Therapeutic Approaches of Exosomes. Cells 2019, 8, 307. [CrossRef]

18. Thery, C.; Zitvogel, L.; Amigorena, S. Exosomes: Composition, biogenesis and function. Nat. Rev. Immunol. 2002, 2, 569-579. [CrossRef]

19. Babst, M.; Katzmann, D.J.; Estepa-Sabal, E.J.; Meerloo, T.; Emr, S.D. Escrt-III: An endosome-associated heterooligomeric protein complex required for mvb sorting. Dev. Cell 2002, 3, 271-282. [CrossRef]

20. Wollert, T.; Hurley, J.H. Molecular mechanism of multivesicular body biogenesis by ESCRT complexes. Nature 2010, 464, 864-869. [CrossRef]

21. Trajkovic, K.; Hsu, C.; Chiantia, S.; Rajendran, L.; Wenzel, D.; Wieland, F.; Schwille, P.; Brugger, B.; Simons, M. Ceramide triggers budding of exosome vesicles into multivesicular Endosomes. Science 2008, 319, 1244-1247. [CrossRef]

22. Bebelman, M.P.; Smit, M.J.; Pegtel, D.M.; Baglio, S.R. Biogenesis and function of extracellular vesicles in cancer. Pharmacol. Ther. 2018, 188, 1-11. [CrossRef]

23. Simons, M.; Raposo, G. Exosomes-vesicular carriers for intercellular communication. Curr. Opin. Cell Biol. 2009, $21,575-581$. [CrossRef]

24. Thery, C.; Ostrowski, M.; Segura, E. Membrane vesicles as conveyors of immune responses. Nat. Rev. Immunol. 2009, 9, 581-593. [CrossRef] [PubMed]

25. Mathivanan, S.; Simpson, R.J. ExoCarta: A compendium of exosomal proteins and RNA. Proteomics 2009, 9, 4997-5000. [CrossRef] [PubMed]

26. Christ, L.; Raiborg, C.; Wenzel, E.M.; Campsteijn, C.; Stenmark, H. Cellular Functions and Molecular Mechanisms of the ESCRT Membrane-Scission Machinery. Trends Biochem. Sci. 2017, 42, 42-56. [CrossRef]

27. Raiborg, C.; Stenmark, H. The ESCRT machinery in endosomal sorting of ubiquitylated membrane proteins. Nature 2009, 458, 445-452. [CrossRef] [PubMed]

28. Schoneberg, J.; Lee, I.H.; Iwasa, J.H.; Hurley, J.H. Reverse-topology membrane scission by the ESCRT proteins. Nat. Rev. Mol. Cell Biol. 2017, 18, 5-17. [CrossRef]

29. Xu, H.; Dong, X.Y.; Chen, Y.M.; Wang, X.J. Serum exosomal hnRNPH1 mRNA as a novel marker for hepatocellular carcinoma. Clin. Chem. Lab. Med. 2018, 56, 479-484. [CrossRef]

30. Wani, S.; Kaul, D.; Mavuduru, R.S.; Kakkar, N.; Bhatia, A. Urinary-exosomal miR-2909, A novel pathognomonic trait of prostate cancer severity. J. Biotechnol. 2017, 259, 135-139. [CrossRef] 
31. Yang, H.; Fu, H.L.; Wang, B.; Zhang, X.; Mao, J.H.; Li, X.; Wang, M.; Sun, Z.X.; Qian, H.; Xu, W.R. Exosomal miR-423-5p targets SUFU to promote cancer growth and metastasis and serves as a novel marker for gastric cancer. Mol. Carcinogen. 2018, 57, 1223-1236. [CrossRef]

32. Yoshikawa, M.; Iinuma, H.; Umemoto, Y.; Yanagisawa, T.; Matsumoto, A.; Jinno, H. Exosome-encapsulated microRNA-223-3p as a minimally invasive biomarker for the early detection of invasive breast cancer. Oncol. Lett. 2018, 15, 9584-9592. [CrossRef]

33. Kahlert, C.; Melo, S.A.; Protopopov, A.; Tang, J.B.; Seth, S.; Koch, M.; Zhang, J.H.; Weitz, J.; Chin, L.; Futreal, A.; et al. Identification of Double-stranded Genomic DNA Spanning All Chromosomes with Mutated KRAS and p53 DNA in the Serum Exosomes of Patients with Pancreatic Cancer. J. Biol. Chem. 2014, 289, 3869-3875. [CrossRef]

34. Williams, C.; Rodriguez-Barrueco, R.; Silva, J.M.; Zhang, W.J.; Hearn, S.; Elemento, O.; Paknejad, N.; Manova-Todorova, K.; Welte, K.; Bromberg, J.; et al. Double-stranded DNA in exosomes: A novel biomarker in cancer detection. Cell Res. 2014, 24, 766-769.

35. Garcia-Romero, N.; Carrion-Navarro, J.; Esteban-Rubio, S.; Lazaro-Ibanez, E.; Peris-Celda, M.; Alonso, M.M.; Guzman-DeVilloria, J.; Fernandez-Carballal, C.; de Mendivil, A.O.; Garcia-Duque, S.; et al. DNA sequences within glioma-derived extracellular vesicles can cross the intact blood-brain barrier and be detected in peripheral blood of patients. Oncotarget 2017, 8, 1416-1428. [CrossRef]

36. Melo, S.A.; Luecke, L.B.; Kahlert, C.; Fernandez, A.F.; Gammon, S.T.; Kaye, J.; LeBleu, V.S.; Mittendorf, E.A.; Weitz, J.; Rahbari, N.; et al. Glypican-1 identifies cancer exosomes and detects early pancreatic cancer. Nature 2015, 523, 177-182. [CrossRef]

37. Logozzi, M.; De Milito, A.; Lugini, L.; Borghi, M.; Calabro, L.; Spada, M.; Perdicchio, M.; Marino, M.L.; Federici, C.; Iessi, E.; et al . High Levels of Exosomes Expressing CD63 and Caveolin-1 in Plasma of Melanoma Patients. PLoS ONE 2009, 4, e5219. [CrossRef]

38. Yoshioka, Y.; Konishi, Y.; Kosaka, N.; Katsuda, T.; Kato, T.; Ochiya, T. Comparative marker analysis of extracellular vesicles in different human cancer types. J. Extracell. Vesicles 2013, 2, 20424. [CrossRef] [PubMed]

39. Jo, W.; Jeong, D.; Kim, J.; Park, J. Self-Renewal of Bone Marrow Stem Cells by Nanovesicles Engineered from Embryonic Stem Cells. Adv. Healthc. Mater. 2016, 5, 3148-3156. [CrossRef] [PubMed]

40. Rani, S.; Ritter, T. The Exosome-A Naturally Secreted Nanoparticle and its Application to Wound Healing. Adv. Mater. 2016, 28, 5542-5552. [CrossRef] [PubMed]

41. Lindenbergh, M.F.S.; Stoorvogel, W. Antigen Presentation by Extracellular Vesicles from Professional Antigen-Presenting Cells. Annu. Rev. Immunol. 2018, 36, 435-459. [CrossRef]

42. Andaloussi, S.E.; Mager, I.; Breakefield, X.O.; Wood, M.J. Extracellular vesicles: Biology and emerging therapeutic opportunities. Nat. Rev. Drug Discov. 2013, 12, 347-357. [CrossRef]

43. Figueroa, J.M.; Skog, J.; Akers, J.; Li, H.Y.; Komotar, R.; Jensen, R.; Ringel, F.; Yang, I.; Kalkanis, S.; Thompson, R.; et al. Detection of wild-type EGFR amplification and EGFRvIII mutation in CSF-derived extracellular vesicles of glioblastoma patients. Neuro-Oncology 2017, 19, 1494-1502. [CrossRef]

44. Skog, J.; Wurdinger, T.; van Rijn, S.; Meijer, D.H.; Gainche, L.; Sena-Esteves, M.; Curry, W.T.; Carter, B.S.; Krichevsky, A.M.; Breakefield, X.O. Glioblastoma microvesicles transport RNA and proteins that promote tumour growth and provide diagnostic biomarkers. Nat. Cell Biol. 2008, 10, 1470-1476. [CrossRef]

45. Shao, N.Y.; Xue, L.; Wang, R.; Luo, K.M.; Zhi, F.; Lan, Q. miR-454-3p Is an Exosomal Biomarker and Functions as a Tumor Suppressor in Glioma. Mol. Cancer Ther. 2019, 18, 459-469. [CrossRef]

46. Manterola, L.; Guruceaga, E.; Perez-Larraya, J.G.; Gonzalez-Huarriz, M.; Jauregui, P.; Tejada, S.; Diez-Valle, R.; Segura, V.; Sampron, N.; Barrena, C.; et al. A small noncoding RNA signature found in exosomes of GBM patient serum as a diagnostic tool. Neuro-Oncology 2014, 16, 520-527. [CrossRef] [PubMed]

47. Zhang, L.; Xiao, H.; Zhou, H.; Santiago, S.; Lee, J.M.; Garon, E.B.; Yang, J.P.; Brinkmann, O.; Yan, X.M.; Akin, D.; et al. Development of transcriptomic biomarker signature in human saliva to detect lung cancer. Cell Mol. Life Sci. 2012, 69, 3341-3350. [CrossRef] [PubMed]

48. Kanaoka, R.; Iinuma, H.; Dejima, H.; Sakai, T.; Uehara, H.; Matsutani, N.; Kawamura, M. Usefulness of Plasma Exosomal MicroRNA-451a as a Noninvasive Biomarker for Early Prediction of Recurrence and Prognosis of Non-Small Cell Lung Cancer. Oncology 2018, 94, 311-323. [CrossRef]

49. Yuwen, D.L.; Ma, Y.Z.; Wang, D.Q.; Gao, J.; Li, X.; Xue, W.W.; Fan, M.M.; Xu, Q.; Shen, Y.; Shu, Y.Q. Prognostic Role of Circulating Exosomal miR-425-3p for the Response of NSCLC to Platinum-Based Chemotherapy. Cancer Epidemiol. Prev. Biomark. 2019, 28, 163-173. [CrossRef] [PubMed]

50. Dejima, H.; Iinuma, H.; Kanaoka, R.; Matsutani, N.; Kawamura, M. Exosomal microRNA in plasma as a non-invasive biomarker for the recurrence of non-small cell lung cancer. Oncol. Lett. 2017, 13, 1256-1263. [CrossRef]

51. Gao, J.; Qiu, X.; Li, X.; Fan, H.; Zhang, F.; Lv, T.; Song, Y. Expression profiles and clinical value of plasma exosomal Tim-3 and Galectin-9 in non-small cell lung cancer. Biochem. Biophys. Res. Commun. 2018, 498, 409-415. [CrossRef]

52. Wang, N.; Song, X.; Liu, L.; Niu, L.; Wang, X.; Song, X.; Xie, L. Circulating exosomes contain protein biomarkers of metastatic non-small-cell lung cancer. Cancer Sci. 2018, 109, 1701-1709. [CrossRef]

53. Li, Y.; Zhang, Y.; Qiu, F.; Qiu, Z. Proteomic identification of exosomal LRG1: A potential urinary biomarker for detecting NSCLC. Electrophoresis 2011, 32, 1976-1983. [CrossRef] 
54. Goldvaser, H.; Gutkin, A.; Beery, E.; Edel, Y.; Nordenberg, J.; Wolach, O.; Rabizadeh, E.; Uziel, O.; Lahav, M. Characterisation of blood-derived exosomal hTERT mRNA secretion in cancer patients: A potential pan-cancer marker. Br. J. Cancer 2017, 117, 353-357. [CrossRef] [PubMed]

55. Moon, P.G.; Lee, J.E.; Cho, Y.E.; Lee, S.J.; Chae, Y.S.; Jung, J.H.; Kim, I.S.; Park, H.Y.; Baek, M.C. Fibronectin on circulating extracellular vesicles as a liquid biopsy to detect breast cancer. Oncotarget 2016, 7, 40189-40199. [CrossRef]

56. Tanaka, Y.; Kamohara, H.; Kinoshita, K.; Kurashige, J.; Ishimoto, T.; Iwatsuki, M.; Watanabe, M.; Baba, H. Clinical impact of serum exosomal microRNA-21 as a clinical biomarker in human esophageal squamous cell carcinoma. Cancer-Am. Cancer Soc. 2013, 119, 1159-1167. [CrossRef] [PubMed]

57. Chiam, K.; Wang, T.T.; Watson, D.I.; Mayne, G.C.; Irvine, T.S.; Bright, T.; Smith, L.; White, I.A.; Bowen, J.M.; Keefe, D.; et al. Circulating Serum Exosomal miRNAs As Potential Biomarkers for Esophageal Adenocarcinoma. J. Gastrointest. Surg. 2015, 19, 1208-1215. [CrossRef]

58. Tokuhisa, M.; Ichikawa, Y.; Kosaka, N.; Ochiya, T.; Yashiro, M.; Hirakawa, K.; Kosaka, T.; Makino, H.; Akiyama, H.; Kunisaki, C.; et al. Exosomal miRNAs from Peritoneum Lavage Fluid as Potential Prognostic Biomarkers of Peritoneal Metastasis in Gastric Cancer. PLoS ONE 2015, 10, e0130472. [CrossRef]

59. Kumata, Y.; Iinuma, H.; Suzuki, Y.; Tsukahara, D.; Midorikawa, H.; Igarashi, Y.; Soeda, N.; Kiyokawa, T.; Horikawa, M.; Fukushima, R. Exosome-encapsulated microRNA-23b as a minimally invasive liquid biomarker for the prediction of recurrence and prognosis of gastric cancer patients in each tumor stage. Oncol. Rep. 2018, 40, 319-330. [CrossRef]

60. Zhang, X.; Liang, W.; Liu, J.B.; Zang, X.Y.; Gu, J.M.; Pan, L.; Shi, H.; Fu, M.; Huang, Z.H.; Zhang, Y.; et al. Long non-coding RNA UFC1 promotes gastric cancer progression by regulating miR-498/Lin28b. J. Exp. Clin. Cancer Res. 2018, 37, 134. [CrossRef] [PubMed]

61. Fu, H.L.; Yang, H.; Zhang, X.; Wang, B.; Mao, J.H.; Li, X.; Wang, M.; Zhang, B.; Sun, Z.X.; Qian, H.; et al. Exosomal TRIM3 is a novel marker and therapy target for gastric cancer. J. Exp. Clin. Cancer Res. 2018, 37, 162. [CrossRef]

62. Dong, L.; Lin, W.R.; Qi, P.; Xu, M.D.; Wu, X.B.; Ni, S.J.; Huang, D.; Weng, W.W.; Tan, C.; Sheng, W.Q.; et al. Circulating Long RNAs in Serum Extracellular Vesicles: Their Characterization and Potential Application as Biomarkers for Diagnosis of Colorectal Cancer. Cancer Epidemiol. Prev. Biomark. 2016, 25, 1158-1166. [CrossRef]

63. Yan, S.S.; Jiang, Y.; Liang, C.H.; Cheng, M.; Jin, C.W.; Duan, Q.H.; Xu, D.H.; Yang, L.; Zhang, X.Y.; Ren, B.; et al. Exosomal miR-6803-5p as potential diagnostic and prognostic marker in colorectal cancer. J. Cell Biochem. 2018, 119, 4113-4119. [CrossRef]

64. Fu, F.F.; Jiang, W.Q.; Zhou, L.F.; Chen, Z. Circulating Exosomal miR-17-5p and miR-92a-3p Predict Pathologic Stage and Grade of Colorectal Cancer. Transl. Oncol. 2018, 11, 221-232. [CrossRef] [PubMed]

65. Li, Y.; Zheng, Q.P.; Bao, C.Y.; Li, S.Y.; Guo, W.J.; Zhao, J.; Chen, D.; Gu, J.R.; He, X.H.; Huang, S.L. Circular RNA is enriched and stable in exosomes: A promising biomarker for cancer diagnosis. Cell Res. 2015, 25, 981-984. [CrossRef]

66. Xiao, Y.; Li, Y.; Yuan, Y.H.; Liu, B.; Pan, S.M.; Liu, Q.Q.; Qi, X.; Zhou, H.M.; Dong, W.J.; Jia, L. The potential of exosomes derived from colorectal cancer as a biomarker. Clin. Chim. Acta 2019, 490, 186-193. [CrossRef]

67. Santasusagna, S.; Moreno, I.; Navarro, A.; Castellano, J.J.; Martinez, F.; Hernandez, R.; Munoz, C.; Monzo, M. Proteomic Analysis of Liquid Biopsy from Tumor-Draining Vein Indicates that High Expression of Exosomal ECM1 Is Associated with Relapse in Stage I-III Colon Cancer. Transl. Oncol. 2018, 11, 715-721. [CrossRef]

68. Sun, B.; Li, Y.M.; Zhou, Y.M.; Ng, T.K.; Zhao, C.; Gan, Q.Q.; Gu, X.D.; Xiang, J.B. Circulating exosomal CPNE3 as a diagnostic and prognostic biomarker for colorectal cancer. J. Cell Physiol. 2019, 234, 1416-1425. [CrossRef] [PubMed]

69. Shi, M.; Jiang, Y.; Yang, L.; Yan, S.S.; Wang, Y.G.; Lu, X.J. Decreased levels of serum exosomal miR-638 predict poor prognosis in hepatocellular carcinoma. J. Cell Biochem. 2018, 119, 4711-4716. [CrossRef]

70. Wang, Y.R.; Zhang, C.Y.; Zhang, P.J.; Guo, G.H.; Jiang, T.; Zhao, X.M.; Jiang, J.J.; Huang, X.L.; Tong, H.L.; Tian, Y.P. Serum exosomal microRNAs combined with alpha-fetoprotein as diagnostic markers of hepatocellular carcinoma. Cancer Med. 2018, 7, 1670-1679. [CrossRef] [PubMed]

71. Xu, H.; Chen, Y.M.; Dong, X.Y.; Wang, X.J. Serum Exosomal Long Noncoding RNAs ENSG00000258332.1 and LINC00635 for the Diagnosis and Prognosis of Hepatocellular Carcinoma. Cancer Epidemiol. Prev. Biomark. 2018, 27, 710-716. [CrossRef]

72. Arbelaiz, A.; Azkargorta, M.; Krawczyk, M.; Santos-Laso, A.; Lapitz, A.; Perugorria, M.; Erice, O.; Gonzalez, E.; JimenezAguero, R.; Lacasta, A.; et al. Serum extracellular vesicles contain protein biomarkers for primary sclerosing cholangitis (PSC), cholangiocarcinoma (CCA) and hepatocellular carcinoma (HCC). Hepatology 2017, 66, 1125-1143. [CrossRef] [PubMed]

73. Goto, T.; Fujiya, M.; Konishi, H.; Sasajima, J.; Fujibayashi, S.; Hayashi, A.; Utsumi, T.; Sato, H.; Iwama, T.; Ijiri, M.; et al. An elevated expression of serum exosomal microRNA-191,-21,-451a of pancreatic neoplasm is considered to be efficient diagnostic marker. BMC Cancer 2018, 18, 116. [CrossRef] [PubMed]

74. Zhan, Y.; Du, L.T.; Wang, L.S.; Jiang, X.M.; Zhang, S.J.; Li, J.; Yan, K.Q.; Duan, W.L.; Zhao, Y.H.; Wang, L.L.; et al. Expression signatures of exosomal long non-coding RNAs in urine serve as novel non-invasive biomarkers for diagnosis and recurrence prediction of bladder cancer. Mol. Cancer 2018, 17, 142. [CrossRef]

75. Capitanio, D.; Moriggi, M.; Torretta, E.; Barbacini, P.; De Palma, S.; Vigano, A.; Lochmuller, H.; Muntoni, F.; Ferlini, A.; Mora, M.; et al. Comparative proteomic analyses of Duchenne muscular dystrophy and Becker muscular dystrophy muscles: Changes contributing to preserve muscle function in Becker muscular dystrophy patients. J. Cachexia Sarcopenia Muscle 2020, 11, 547-563. [CrossRef] [PubMed] 
76. Beckham, C.J.; Olsen, J.; Yin, P.N.; Wu, C.H.; Ting, H.J.; Hagen, F.K.; Scosyrev, E.; Messing, E.M.; Lee, Y.F. Bladder Cancer Exosomes Contain EDIL-3/Del1 and Facilitate Cancer Progression. J. Urol. 2014, 192, 583-592. [CrossRef]

77. Zhang, W.; Ni, M.W.; Su, Y.; Wang, H.; Zhu, S.X.; Zhao, A.; Li, G.R. MicroRNAs in Serum Exosomes as Potential Biomarkers in Clear-cell Renal Cell Carcinoma. Eur. Urol. Focus 2018, 4, 412-419. [CrossRef]

78. Raimondo, F.; Morosi, L.; Corbetta, S.; Chinello, C.; Brambilla, P.; Della Mina, P.; Villa, A.; Albo, G.; Battaglia, C.; Bosari, S.; et al. Differential protein profiling of renal cell carcinoma urinary exosomes. Mol. Biosyst. 2013, 9, 1220-1233. [CrossRef]

79. Testa, A.; Venturelli, E.; Brizzi, M.F. Extracellular Vesicles as a Novel Liquid Biopsy-Based Diagnosis for the Central Nervous System, Head and Neck, Lung, and Gastrointestinal Cancers: Current and Future Perspectives. Cancers 2021, 13, 2792. [CrossRef]

80. Testa, A.; Venturelli, E.; Brizzi, M.F. Extracellular Vesicles: New Tools for Early Diagnosis of Breast and Genitourinary Cancers. Int. J. Mol. Sci. 2021, 22, 8430. [CrossRef]

81. Weston, W.W.; Ganey, T.; Temple, H.T. The Relationship between Exosomes and Cancer: Implications for Diagnostics and Therapeutics. Biodrugs 2019, 33, 137-158. [CrossRef] [PubMed]

82. Sung, B.H.; Ketova, T.; Hoshino, D.; Zijlstra, A.; Weaver, A.M. Directional cell movement through tissues is controlled by exosome secretion. Nat. Commun. 2015, 6, 7164. [CrossRef]

83. Lopatina, T.; Grange, C.; Cavallari, C.; Navarro-Tableros, V.; Lombardo, G.; Rosso, A.; Cedrino, M.; Pomatto, M.; Alba, C.; Koni, M.; et al. Targeting IL-3R $\alpha$ on tumor-derived endothelial cells blunts metastatic spread of triple-negative breast cancer via extracellular vesicle reprogramming. Oncogenesis 2020, 9, 90. [CrossRef] [PubMed]

84. Taylor, D.D.; Gercel-Taylor, C. MicroRNA signatures of tumor-derived exosomes as diagnostic biomarkers of ovarian cancer. Gynecol. Oncol. 2008, 110, 13-21, Erratum in Gynecol. Oncol. 2010, 116, 153. [CrossRef] [PubMed]

85. Tian, Y.; Gong, M.F.; Hu, Y.Y.; Liu, H.S.; Zhang, W.Q.; Zhang, M.M.; Hu, X.X.; Aubert, D.; Zhu, S.B.; Wu, L.; et al. Quality and efficiency assessment of six extracellular vesicle isolation methods by nano-flow cytometry. J. Extracell. Vesicles 2020, 9, 1697028. [CrossRef]

86. Fang, X.; Chen, C.; Liu, B.; Ma, Z.; Hu, F.; Li, H.; Gu, H.; Xu, H. A magnetic bead-mediated selective adsorption strategy for extracellular vesicle separation and purification. Acta Biomater. 2021, 124, 336-347. [CrossRef] [PubMed]

87. Brett, S.I.; Lucien, F.; Guo, C.; Williams, K.C.; Kim, Y.; Durfee, P.N.; Brinker, C.J.; Chin, J.I.; Yang, J.; Leong, H.S. Immunoaffinity based methods are superior to kits for purification of prostate derived extracellular vesicles from plasma samples. Prostate 2017, 77, 1335-1343. [CrossRef]

88. Pandey, C.M.; Augustine, S.; Kumar, S.; Kumar, S.; Nara, S.; Srivastava, S.; Malhotra, B.D. Microfluidics Based Point-of-Care Diagnostics. Biotechnol. J. 2018, 13, 1700047. [CrossRef]

89. Wang, C.; Zhang, D.; Yang, L.; Liu, Y.; Wu, Y. Application of Microfluidics in Molecular Diagnostics. Zhongguo Yi Liao Qi Xie Za Zhi 2020, 44, 520-524.

90. Sackmann, E.K.; Fulton, A.L.; Beebe, D.J. The present and future role of microfluidics in biomedical research. Nature 2014, 507, 181-189. [CrossRef]

91. Gamez-Valero, A.; Monguio-Tortajada, M.; Carreras-Planella, L.; Franquesa, M.-L.; Beyer, K.; Borras, F.E. Size-Exclusion Chromatography-based isolation minimally alters Extracellular Vesicles' characteristics compared to precipitating agents. Sci. Rep. 2016, 6, 33641. [CrossRef] [PubMed]

92. An, M.R.; Wu, J.; Zhu, J.H.; Lubman, D.M. Comparison of an Optimized Ultracentrifugation Method versus Size-Exclusion Chromatography for Isolation of Exosomes from Human Serum. J. Proteome Res. 2018, 17, 3599-3605. [CrossRef] [PubMed]

93. Stranska, R.; Gysbrechts, L.; Wouters, J.; Vermeersch, P.; Bloch, K.; Dierickx, D.; Andrei, G.; Snoeck, R. Comparison of membrane affinity-based method with size-exclusion chromatography for isolation of exosome-like vesicles from human plasma. J. Transl. Med. 2018, 16, 1. [CrossRef] [PubMed]

94. Ma, C.Y.; Jiang, F.; Ma, Y.F.; Wang, J.Q.; Li, H.J.; Zhang, J.J. Isolation and Detection Technologies of Extracellular Vesicles and Application on Cancer Diagnostic. Dose-Response 2019, 17, 1559325819891004. [CrossRef] [PubMed]

95. Yang, D.B.; Zhang, W.H.; Zhang, H.Y.; Zhang, F.Q.; Chen, L.M.; Ma, L.X.; Larcher, L.M.; Chen, S.X.; Liu, N.; Zhao, Q.X.; et al. Progress, opportunity, and perspective on exosome isolation-efforts for efficient exosome-based theranostics. Theranostics $\mathbf{2 0 2 0}$ 10, 3684-3707. [CrossRef]

96. Taly, V.; Pekin, D.; Benhaim, L.; Kotsopoulos, S.K.; Le Corre, D.; Li, X.Y.; Atochin, I.; Link, D.R.; Griffiths, A.D.; Pallier, K.; et al. Multiplex Picodroplet Digital PCR to Detect KRAS Mutations in Circulating DNA from the Plasma of Colorectal Cancer Patients. Clin. Chem. 2013, 59, 1722-1731. [CrossRef] [PubMed]

97. Zhong, Q.; Bhattacharya, S.; Kotsopoulos, S.; Olson, J.; Taly, V.; Griffiths, A.D.; Link, D.R.; Larson, J.W. Multiplex digital PCR: Breaking the one target per color barrier of quantitative PCR. Lab Chip 2011, 11, 2167-2174. [CrossRef]

98. Hindson, B.J.; Ness, K.D.; Masquelier, D.A.; Belgrader, P.; Heredia, N.J.; Makarewicz, A.J.; Bright, I.J.; Lucero, M.Y.; Hiddessen, A.L.; Legler, T.C.; et al. High-Throughput Droplet Digital PCR System for Absolute Quantitation of DNA Copy Number. Anal. Chem. 2011, 83, 8604-8610. [CrossRef]

99. Williams, R.; Peisajovich, S.G.; Miller, O.J.; Magdassi, S.; Tawfik, D.S.; Griffiths, A.D. Amplification of complex gene libraries by emulsion PCR. Nat. Methods 2006, 3, 545-550. [CrossRef]

100. Gholizadeh, S.; Draz, M.S.; Zarghooni, M.; Sanati-Nezhad, A.; Ghavami, S.; Shafiee, H.; Akbari, M. Microfluidic approaches for isolation, detection, and characterization of extracellular vesicles: Current status and future directions. Biosens. Bioelectron. 2017, 91, 588-605. [CrossRef] 
101. Contreras-Naranjo, J.C.; Wu, H.J.; Ugaz, V.M. Microfluidics for exosome isolation and analysis: Enabling liquid biopsy for personalized medicine. Lab Chip 2017, 17, 3558-3577. [CrossRef] [PubMed]

102. Zhang, P.; Zhou, X.; He, M.; Shang, Y.; Tetlow, A.L.; Godwin, A.K.; Zeng, Y. Ultrasensitive detection of circulating exosomes with a 3D-nanopatterned microfluidic chip. Nat. Biomed. Eng. 2019, 3, 438-451. [CrossRef]

103. Schlucker, S. SERS Microscopy: Nanoparticle Probes and Biomedical Applications. Chemphyschem 2009, 10, 1344-1354. [CrossRef]

104. Kneipp, J.; Kneipp, H.; Kneipp, K. SERS-A single-molecule and nanoscale tool for bioanalytics. Chem. Soc. Rev. 2008, 37, 1052-1060. [CrossRef] [PubMed]

105. Wang, Y.Q.; Yan, B.; Chen, L.X. SERS Tags: Novel Optical Nanoprobes for Bioanalysis. Chem. Rev. 2013, 113, 1391-1428. [CrossRef]

106. Zamay, G.S.; Kolovskaya, O.S.; Zamay, T.N.; Glazyrin, Y.E.; Krat, A.V.; Zubkova, O.; Spivak, E.; Wehbe, M.; Gargaun, A.; Muharemagic, D.; et al. Aptamers Selected to Postoperative Lung Adenocarcinoma Detect Circulating Tumor Cells in Human Blood. Mol. Ther. 2015, 23, 1486-1496. [CrossRef]

107. Boriachek, K.; Islam, M.N.; Gopalan, V.; Lam, A.K.; Nguyen, N.T.; Shiddiky, M.J.A. Quantum dot-based sensitive detection of disease specific exosome in serum. Analyst 2017, 142, 2211-2219. [CrossRef] [PubMed]

108. Schure, M.; Moran, R.; Schuster, S.; Wagner, B.; Luo, C.P. Size exclusion chromatography with superficially porous particles. Abstr. Pap. Am. Chem. S. 2017, 1480, 11-19. [CrossRef] [PubMed]

109. Zheng, L.; Zheng, L.; Li, B.; Liu, C.C.; Pan, W.L. New technology for analysis of extracellular vesicles towards clinical diagnosis. Cancer Sci. 2021, 112, 985.

110. Boing, A.N.; van der Pol, E.; Grootemaat, A.E.; Coumans, F.A.; Sturk, A.; Nieuwland, R. Single-step isolation of extracellular vesicles by size-exclusion chromatography. J. Extracell. Vesicles 2014, 3, 23430. [CrossRef]

111. Zhang, Y.; Deng, Z.; Lou, D.; Wang, Y.; Wang, R.; Hu, R.; Zhang, X.; Zhu, Q.; Chen, Y.; Liu, F. High-Efficiency Separation of Extracellular Vesicles from Lipoproteins in Plasma by Agarose Gel Electrophoresis. Anal. Chem. 2020, 92, 7493-7499. [CrossRef] [PubMed]

112. Gilboa, T.; Maley, A.M.; Ogata, A.F.; Wu, C.; Walt, D.R. Sequential Protein Capture in Multiplex Single Molecule Arrays: A Strategy for Eliminating Assay Cross-Reactivity. Adv. Healthc. Mater. 2021, 10, e2001111. [CrossRef] [PubMed]

113. Wang, P.; Jing, F.; Li, G.; Wu, Z.; Cheng, Z.; Zhang, J.; Zhang, H.; Jia, C.; Jin, Q.; Mao, H.; et al. Absolute quantification of lung cancer related microRNA by droplet digital PCR. Biosens. Bioelectron. 2015, 74, 836-842. [CrossRef] [PubMed]

114. Rissin, D.M.; Kan, C.W.; Campbell, T.G.; Howes, S.C.; Fournier, D.R.; Song, L.; Piech, T.; Patel, P.P.; Chang, L.; Rivnak, A.J.; et al Single-molecule enzyme-linked immunosorbent assay detects serum proteins at subfemtomolar concentrations. Nat. Biotechnol. 2010, 28, 595-599. [CrossRef] [PubMed]

115. Tian, Q.; He, C.; Liu, G.; Zhao, Y.; Hui, L.; Mu, Y.; Tang, R.K.; Luo, Y.; Zheng, S.; Wang, B. Nanoparticle Counting by Microscopic Digital Detection: Selective Quantitative Analysis of Exosomes via Surface-Anchored Nucleic Acid Amplification. Anal. Chem. 2018, 90, 6556-6562. [CrossRef]

116. Cohen, L.; Cui, N.W.; Cai, Y.M.; Garden, P.M.; Li, X.; Weitz, D.A.; Walt, D.R. Single Molecule Protein Detection with Attomolar Sensitivity Using Droplet Digital Enzyme-Linked Immunosorbent Assay. ACS Nano 2020, 14, 9491-9501. [CrossRef]

117. Pinheiro, L.B.; Coleman, V.A.; Hindson, C.M.; Herrmann, J.; Hindson, B.J.; Bhat, S.; Emslie, K.R. Evaluation of a Droplet Digital Polymerase Chain Reaction Format for DNA Copy Number Quantification. Anal. Chem. 2012, 84, 1003-1011. [CrossRef]

118. Cho, S.M.; Shin, S.; Kim, Y.; Song, W.; Hong, S.G.; Jeong, S.H.; Kang, M.S.; Lee, K.A. A novel approach for tuberculosis diagnosis using exosomal DNA and droplet digital PCR. Clin. Microbiol. Infect. 2020, 26, 942.e1-942.e5. [CrossRef]

119. Lin, B.Q.; Tian, T.; Lu, Y.Z.; Liu, D.; Huang, M.J.; Zhu, L.; Zhu, Z.; Song, Y.L.; Yang, C.Y. Tracing Tumor-Derived Exosomal PD-L1 by Dual-Aptamer Activated Proximity-Induced Droplet Digital PCR. Angew. Chem. Int. Ed. 2021, 60, 7582-7586. [CrossRef]

120. He, M.; Zeng, Y. Microfluidic Exosome Analysis toward Liquid Biopsy for Cancer. J. Lab. Autom. 2016, 21, 599-608. [CrossRef]

121. Liu, C.; Feng, Q.; Sun, J.S. Lipid Nanovesicles by Microfluidics: Manipulation, Synthesis, and Drug Delivery. Adv. Mater. 2019, 31, 1804788. [CrossRef]

122. Wu, M.X.; Ouyang, Y.S.; Wang, Z.Y.; Zhang, R.; Huang, P.H.; Chen, C.Y.; Li, H.; Li, P.; Quinn, D.; Dao, M.; et al. Isolation of exosomes from whole blood by integrating acoustics and microfluidics. Proc. Natl. Acad. Sci. USA 2017, 114, 10584-10589, Erratum in Proc. Natl. Acad. Sci. USA 2020, 117, 28525. [CrossRef] [PubMed]

123. Bruus, H.; Dual, J.; Hawkes, J.; Hill, M.; Laurell, T.; Nilsson, J.; Radel, S.; Sadhal, S.; Wiklund, M. Forthcoming Lab on a Chip tutorial series on acoustofluidics: Acoustofluidics-exploiting ultrasonic standing wave forces and acoustic streaming in microfluidic systems for cell and particle manipulation. Lab Chip 2011, 11, 3579-3580. [CrossRef] [PubMed]

124. Yeo, L.Y.; Friend, J.R. Surface Acoustic Wave Microfluidics. Annu. Rev. Fluid Mech. 2014, 46, 379-406. [CrossRef]

125. Lee, K.; Shao, H.L.; Weissleder, R.; Lee, H. Acoustic Purification of Extracellular Microvesicles. ACS Nano 2015, 9, $2321-2327$. [CrossRef]

126. Liu, C.C.; Xu, X.N.; Li, B.; Situ, B.; Pan, W.L.; Hu, Y.; An, T.X.; Yao, S.H.; Zheng, L. Single-Exosome-Counting Immunoassays for Cancer Diagnostics. Nano Lett. 2018, 18, 4226-4232. [CrossRef]

127. Zhao, Z.; Yang, Y.; Zeng, Y.; He, M. A microfluidic ExoSearch chip for multiplexed exosome detection towards blood-based ovarian cancer diagnosis. Lab Chip 2016, 16, 489-496. [CrossRef]

128. Kanwar, S.S.; Dunlay, C.J.; Simeone, D.M.; Nagrath, S. Microfluidic device (ExoChip) for on-chip isolation, quantification and characterization of circulating exosomes. Lab Chip 2014, 14, 1891-1900. [CrossRef] 
129. Gill, D.; Kilponen, R.G.; Rimai, L. Resonance Raman scattering of laser radiation by vibrational modes of carotenoid pigment molecules in intact plant tissues. Nature 1970, 227, 743-744. [CrossRef]

130. Xu, H.Y.; Liao, C.; Zuo, P.; Liu, Z.W.; Ye, B.C. Magnetic-Based Microfluidic Device for On-Chip Isolation and Detection of Tumor-Derived Exosomes. Anal. Chem. 2018, 90, 13451-13458. [CrossRef]

131. Stremersch, S.; Marro, M.; Pinchasik, B.E.; Baatsen, P.; Hendrix, A.; De Smedt, S.C.; Loza-Alvarez, P.; Skirtach, A.G.; Raemdonck, K.; Braeckmans, K. Identification of Individual Exosome-Like Vesicles by Surface Enhanced Raman Spectroscopy. Small 2016, 12, 3292-3301. [CrossRef]

132. Lee, C.; Carney, R.P.; Hazari, S.; Smith, Z.J.; Knudson, A.; Robertson, C.S.; Lam, K.S.; Wachsmann-Hogiu, S. 3D plasmonic nanobowl platform for the study of exosomes in solution. Nanoscale 2015, 7, 9290-9297. [CrossRef]

133. Park, J.; Hwang, M.; Choi, B.; Jeong, H.; Jung, J.H.; Kim, H.K.; Hong, S.; Park, J.H.; Choi, Y. Exosome Classification by Pattern Analysis of Surface-Enhanced Raman Spectroscopy Data for Lung Cancer Diagnosis. Anal. Chem. 2017, 89, 6695-6701. [CrossRef]

134. Shin, H.; Jeong, H.; Park, J.; Hong, S.; Choi, Y. Correlation between Cancerous Exosomes and Protein Markers Based on SurfaceEnhanced Raman Spectroscopy (SERS) and Principal Component Analysis (PCA). ACS Sens. 2018, 3, 2637-2643. [CrossRef]

135. Wang, Y.; Li, Q.; Shi, H.; Tang, K.; Qiao, L.; Yu, G.; Ding, C.; Yu, S. Microfluidic Raman biochip detection of exosomes: A promising tool for prostate cancer diagnosis. Lab Chip 2020, 20, 4632-4637. [CrossRef]

136. Shin, H.; Oh, S.; Hong, S.; Kang, M.; Kang, D.; Ji, Y.G.; Choi, B.H.; Kang, K.W.; Jeong, H.; Park, Y.; et al. Early-Stage Lung Cancer Diagnosis by Deep Learning-Based Spectroscopic Analysis of Circulating Exosomes. ACS Nano 2020, 14, 5435-5444. [CrossRef] [PubMed]

137. Hassan, E.M.; Willmore, W.G.; DeRosa, M.C. Aptamers: Promising Tools for the Detection of Circulating Tumor Cells. Nucleic Acid Ther. 2016, 26, 335-347. [CrossRef]

138. Yoshida, M.; Hibino, K.; Yamamoto, S.; Matsumura, S.; Yajima, Y.; Shiba, K. Preferential capture of EpCAM-expressing extracellular vesicles on solid surfaces coated with an aptamer-conjugated zwitterionic polymer. Biotechnol. Bioeng. 2018, 115, 536-544. [CrossRef]

139. Kaushik, A.M.; Hsieh, K.; Wang, T.H. Droplet microfluidics for high-sensitivity and high-throughput detection and screening of disease biomarkers. Wiley Interdiscip. Rev. Nanomed. Nanobiotechnol. 2018, 10, e1522. [CrossRef] [PubMed]

140. Darmanis, S.; Nong, R.Y.; Hammond, M.; Gu, J.J.; Alderborn, A.; Vanelid, J.; Siegbahn, A.; Gustafsdottir, S.; Ericsson, O.; Landegren, U.; et al. Sensitive Plasma Protein Analysis by Microparticle-based Proximity Ligation Assays. Mol. Cell Proteom. 2010, 9, 327-335. [CrossRef] [PubMed]

141. Wan, S.; Zhang, L.Q.; Wang, S.; Liu, Y.; Wu, C.C.; Cui, C.; Sun, H.; Shi, M.L.; Jiang, Y.; Li, L.; et al. Molecular Recognition-Based DNA Nanoassemblies on the Surfaces of Nanosized Exosomes. J. Am. Chem. Soc. 2017, 139, 5289-5292. [CrossRef] [PubMed]

142. Sun, H.; Zu, Y. A Highlight of Recent Advances in Aptamer Technology and Its Application. Molecules 2015, 20, 11959-11980. [CrossRef] [PubMed]

143. Viswanathan, S.; Rani, C.; Ho, J.A.A. Electrochemical immunosensor for multiplexed detection of food-borne pathogens using nanocrystal bioconjugates and MWCNT screen-printed electrode. Talanta 2012, 94, 315-319. [CrossRef] [PubMed]

144. Kong, F.Y.; Xu, B.Y.; Xu, J.J.; Chen, H.Y. Simultaneous electrochemical immunoassay using CdS/DNA and PbS/DNA nanochains as labels. Biosens. Bioelectron. 2013, 39, 177-182. [CrossRef] [PubMed]

145. Shiddiky, M.J.A.; Rauf, S.; Kithva, P.H.; Trau, M. Graphene/quantum dot bionanoconjugates as signal amplifiers in stripping voltammetric detection of EpCAM biomarkers. Biosens. Bioelectron. 2012, 35, 251-257. [CrossRef]

146. Shiddiky, M.J.A.; Kithva, P.H.; Kozak, D.; Trau, M. An electrochemical immunosensor to minimize the nonspecific adsorption and to improve sensitivity of protein assays in human serum. Biosens. Bioelectron. 2012, 38, 132-137. [CrossRef] [PubMed]

147. Zhou, Q.; Rahimian, A.; Son, K.; Shin, D.S.; Patel, T.; Revzin, A. Development of an aptasensor for electrochemical detection of exosomes. Methods 2016, 97, 88-93. [CrossRef]

148. Doldan, X.; Fagundez, P.; Cayota, A.; Laiz, J.; Tosar, J.P. Electrochemical Sandwich Immunosensor for Determination of Exosomes Based on Surface Marker-Mediated Signal Amplification. Anal. Chem. 2016, 88, 10466-10473. [CrossRef]

149. Wu, M.; Chen, Z.; Xie, Q.; Xiao, B.; Zhou, G.; Chen, G.; Bian, Z. One-step quantification of salivary exosomes based on combined aptamer recognition and quantum dot signal amplification. Biosens. Bioelectron. 2021, 171, 112733. [CrossRef]

150. Wang, M.; Pan, Y.; Wu, S.; Sun, Z.; Wang, L.; Yang, J.; Yin, Y.; Li, G. Detection of colorectal cancer-derived exosomes based on covalent organic frameworks. Biosens. Bioelectron. 2020, 169, 112638. [CrossRef]

151. Wang, Z.X.; Wu, H.J.; Fine, D.; Schmulen, J.; Hu, Y.; Godin, B.; Zhang, J.X.J.; Liu, X.W. Ciliated micropillars for the microfluidicbased isolation of nanoscale lipid vesicles. Lab Chip 2013, 13, 2879-2882. [CrossRef]

152. Lim, J.; Choi, M.; Lee, H.; Kim, Y.H.; Han, J.Y.; Lee, E.S.; Cho, Y. Direct isolation and characterization of circulating exosomes from biological samples using magnetic nanowires. J. Nanobiotechnol. 2019, 17, 1. [CrossRef] [PubMed]

153. Scherr, S.M.; Daaboul, G.G.; Trueb, J.; Sevenler, D.; Fawcett, H.; Goldberg, B.; Connor, J.H.; Unlu, M.S. Real-Time Capture and Visualization of Individual Viruses in Complex Media. ACS Nano 2016, 10, 2827-2833. [CrossRef] [PubMed]

154. Hoshino, A.; Kim, H.S.; Bojmar, L.; Gyan, K.E.; Cioffi, M.; Hernandez, J.; Zambirinis, C.P.; Rodrigues, G.; Molina, H.; Heissel, S.; et al. Extracellular Vesicle and Particle Biomarkers Define Multiple Human Cancers. Cell 2020, 182, 1044-1061.e18. [CrossRef] [PubMed] 
155. Crescitelli, R.; Lasser, C.; Jang, S.C.; Cvjetkovic, A.; Malmhall, C.; Karimi, N.; Hoog, J.L.; Johansson, I.; Fuchs, J.; Thorsell, A.; et al. Subpopulations of extracellular vesicles from human metastatic melanoma tissue identified by quantitative proteomics after optimized isolation. J. Extracell. Vesicles 2020, 9, 1722433. [CrossRef] [PubMed]

156. Quaglia, F.; Krishn, S.R.; Daaboul, G.G.; Sarker, S.; Pippa, R.; Domingo-Domenech, J.; Kumar, G.; Fortina, P.; McCue, P.; Kelly, W.K.; et al. Small extracellular vesicles modulated by alphaVbeta3 integrin induce neuroendocrine differentiation in recipient cancer cells. J. Extracell. Vesicles 2020, 9, 1761072. [CrossRef] [PubMed]

157. Harkonen, K.; Oikari, S.; Kyykallio, H.; Capra, J.; Hakkola, S.; Ketola, K.; Thanigai Arasu, U.; Daaboul, G.; Malloy, A.; Oliveira, C.; et al. CD44s Assembles Hyaluronan Coat on Filopodia and Extracellular Vesicles and Induces Tumorigenicity of MKN74 Gastric Carcinoma Cells. Cells 2019, 8, 276. [CrossRef] [PubMed] 